\title{
Low Impact Development Techniques to Mitigate the Impacts of Climate- Change-Induced Urban Floods: Current Trends, Issues and Challenges
}

Sahar Hadi Pour ${ }^{1,2}$,* Ahmad Khairi Abd Wahab ${ }^{1,2}$, Shamsuddin Shahid ${ }^{1,2,3}$, Md. Asaduzzaman $^{4}$, Ashraf Dewan $^{5}$

${ }^{1}$ School of Civil Engineering, Faculty of Engineering, Universiti Teknologi Malaysia (UTM), Johor Bahru 81310, Malaysia;

hpsahar@utm.my; sshahid@utm.my; akhairi@utm.my

${ }^{2}$ Centre for Coastal and Ocean Engineering (COEI), Universiti Teknologi Malaysia (UTM), Johor Bahru 81310, Malaysia

${ }^{3}$ Institute of Oceanography and Environment (INOS), University Malaysia Terengganu (UMT), 21300 Kuala Terengganu, Terengganu, Malaysia

${ }^{4}$ Department of Engineering \& Design, Staffordshire University, Stoke-on-Trent ST4 2DE, UK. Email: md.asaduzzaman@staffs.ac.uk

${ }^{5}$ Spatial Sciences Discipline, School of Earth and Planetary Sciences, Curtin University, Perth, WA 6102, Australia. Email: a.dewan@ curtin.edu.au

*Correspondence: hpsahar@utm.my

\section{Highlights}

- Aggregated impacts of global and urban micro-climate on urban floods are reviewed

- Pros and cons of low impact development in urban flood mitigation are summarized

- Low impact development can lessen climate-change-induced urban flood impacts

- Site-specific selection and optimization are the major challenges of its success 


\begin{abstract}
The severity and frequency of short-duration, but damaging, urban area floods have increased in recent years across the world. Alteration to the urban micro-climate due to global climate change impacts may also exacerbate the situation in future. Sustainable urban stormwater management using low impact development (LID) techniques, along with conventional urban stormwater management systems, can be implemented to mitigate climate-change-induced flood impacts. In this study, the effectiveness of LIDs in the mitigation of urban flood are analyzed to identify their limitations. Further research on the success of these techniques in urban flood mitigation planning is also recommended. The results revealed that LIDs can be an efficient method for mitigating urban flood impacts. Most of the LID methods developed so far, however, are found to be effective only for small flood peaks. They also often fail due to non-optimization of the site-specific and time-varying climatic conditions. Major challenges include identification of the best LID practices for the region of interest, efficiency improvements in technical areas, and site-specific optimization of LID parameters. Improvements in these areas will allow better mitigation of climate-change-induced urban floods in a cost-effective manner and will also assist in the achievement of sustainable development goals for cities.
\end{abstract}

Keywords Climate change, urban floods, adaptation, stormwater management, low impact development

\title{
1. Introduction
}

Global warming is likely to cause a sharp rise in overall world temperature, leading to an increase in evapotranspiration and atmospheric moisture content, and associated changes in rainfall patterns (Wang et al., 2016). Even a small change in rainfall mean and variability can result in a significant increase in rainfall extremes, therefore it is likely that extreme rainfall events will be more intense and recur more often under the influence of a warming climate (Shahid et al., 2016). The effect of warming is also likely to be more severe for urban areas. Higher temperatures resulting from urban heat island (UHI) impacts change the urban microclimate, amplifying the climate variability resulting from global warming, and increasing the severity of rainfall events in these areas (Yang et al. 2013; Ren 2015; Liu and Niyogi 2019; Şimşek and Ödül, 2019). Studies have also noted increased rainfall intensity and higher 
recurrence in large cities, with these effects linked to ongoing urbanization (Yin et al. 2011; Perryman and Dixon 2013; Li et al. 2017b; Wang et al. 2017).

The impacts of extreme rainfall tend to be more severe in paved areas compared to areas with unpaved surfaces. Urban development activities reduce the natural vegetation cover and increase the amount of impervious areas, significantly reducing the rainfall infiltration capacity of the land surface and causing increased surface runoff. Current urban drainage system designs, used to manage runoff to prevent floods, also tend to ignore the impact of ongoing land-use changes on runoff volume and peak. As a result, urbanized areas often experience severe flooding during rainfall events (Ahmed et al. 2017; Anker et al., 2019). In addition, current drainage system designs are usually based on stationary climate data, or the historical characteristics of rainfall estimated over a certain period, without considering the changes in the nature of rainfall over time. The impacts of climate change in increasing the intensity and volume of heavy rainfall events has already caused an increase in flood recurrence times, and associated loss of property, in many cities of the world (Song et al. 2014; Guerreiro et al. 2018; Cooper 2019; Liu and Niyogi 2019).

Urban planners and engineers are now assessing practices which will enable mitigation of increased flood risk arising from climate change. Sustainable urban stormwater management has attracted broad attention as a solution to the challenges of the increasing frequency and severity of these urban flood events. Increasing focus has been given on increasing water infiltration into the sub-surface using low impact development (LID) structures. LID describes a development planning method and approach directed at managing stormwater runoff and increasing infiltration to reduce surface runoff (Sohn et al., 2017; Tredway and Havlick, 2017; Zhan and Chui, 2016). A visual representation of LID methods used to mitigate urban floods is presented in Figure 1. LIDs use natural structures to attenuate and prevent runoff peaks and therefore mitigate flood impacts (Jackisch and Weiler, 2017). Different LID practices, such as green roofs, rain garden, retention systems and porous pavements, have been proposed and variously implemented in the management of urban stormwater. LIDs have shown their effectiveness in significantly reducing water runoff volumes and peaks (Ahmed et al., 2017; Son et al., 2017; Tredway and Havlick, 2017). Due to these factors, LIDs have emerged as an alternative to traditional stormwater management practices, and provide suitable options for the sustainable development of cities and a climate-resilient society (Brunetti et al. 2017; Zhan and Chui 2016; Hu et al. 2017; Seo et al. 2017; Juan et al. 2017; Jackisch and Weiler 2017; Sohn et al. 2017). 


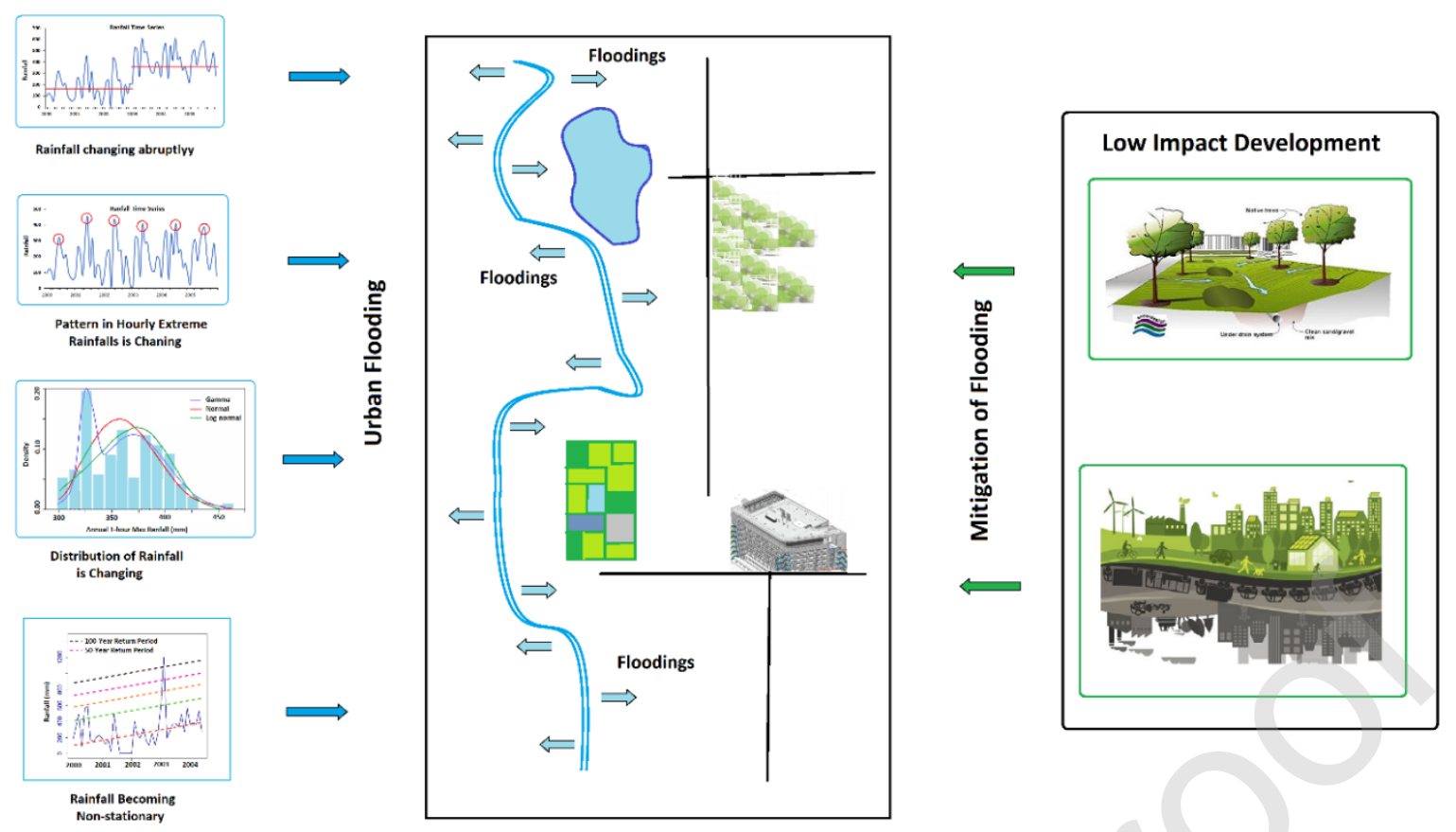

Fig. 1 Infographic, showing increasing frequency and severity of urban flooding due to climate change, and low impact development for mitigation

Numerous studies have reported the effectiveness of LIDs as a means to mitigate urban floods (Jackisch and Weiler 2017; Seo et al. 2017; Tredway and Havlick, 2017; Zhan and Chui, 2016). These studies revealed that the various types of LID practices offer multiple benefits to urban ecosystems and urban runoff in widely-varying geographic and climatic regions (Tredway and Havlick 2017; Sohn et al. 2017). As well as minimizing the impacts of development on the local hydrology, LIDs also conserve the features of the local environment, protect natural habitats, and increase standing groundwater levels (Fletcher et al. 2014; Flanagan et al. 2018). They can also reduce or remove the need for stormwater retention ponds which normally require a large amount of area. LID allows dense urbanization with minimum hydrological impacts, and as a result, has the potential to be a very positive infrastructure development practice in urban development (Zhan and Chui 2016; Seo et al. 2017). LIDs are generally very cost-effective, are climate-resilient and suitable for urban developments which plan to be sustainable. For example, Zhan and Chui (2016) conducted a cost-benefit analysis of LID practices for Hong Kong and reported US $\$ 5.3$ billion in economic benefits and US\$1.2 billion in environmental benefits over a 30 year time period. LIDs also limit the damage to structures from flood events. Hewitt et al. (2019) provided evidence that LIDs helped to reduce building damage from Hurricane Sandy 
in 2012 in New York in the United States. There are, however, some knowledge gaps regarding the capability of different types of LIDs in controlling urban flooding, such as, how LID can be used to address climate change-induced uncertainty in rainfall extremes or what are the challenges in the implementation of LIDs for urban flood mitigation.

The objective of this study is to advance our understanding of the climate change challenges in respect to urban flooding events and to assess the mitigation potential for LIDs in regards warming-induced urban floods. This will also include their possible limitations. The devastation that urban floods can cause is discussed in detail and a literature review is undertaken to determine how climate change can influence the scale of these events. This will assist in clarifying the major challenges to the widespread use of these techniques. The LID tools, and their effectiveness in the mitigation of urban floods, are reviewed in the following section. The challenges involved in the implementation of LIDs are identified, and recommended future research defined.

\section{Urbanization and floods}

\subsection{Trends in urbanization}

Historical population changes, as well as some future potential changes in the global urban population (as a percentage of the total global population), are shown in Fig. 2. The population living in urban areas has increased from less than $30 \%$ in 1950 , to about $55 \%$ at present, an indication of the recent rapid urbanization across the globe. He et al. (2019) reported that 346.4 thousand $\mathrm{km}^{2}$ of the world land surface was urbanized from 1992 to 2016. Angel et al. (2011) reported an increase in global urban coverage from 0.6 million $\mathrm{km}^{2}$ to 0.9 million $\mathrm{km}^{2}$ in the period from 2000 to 2010 . 


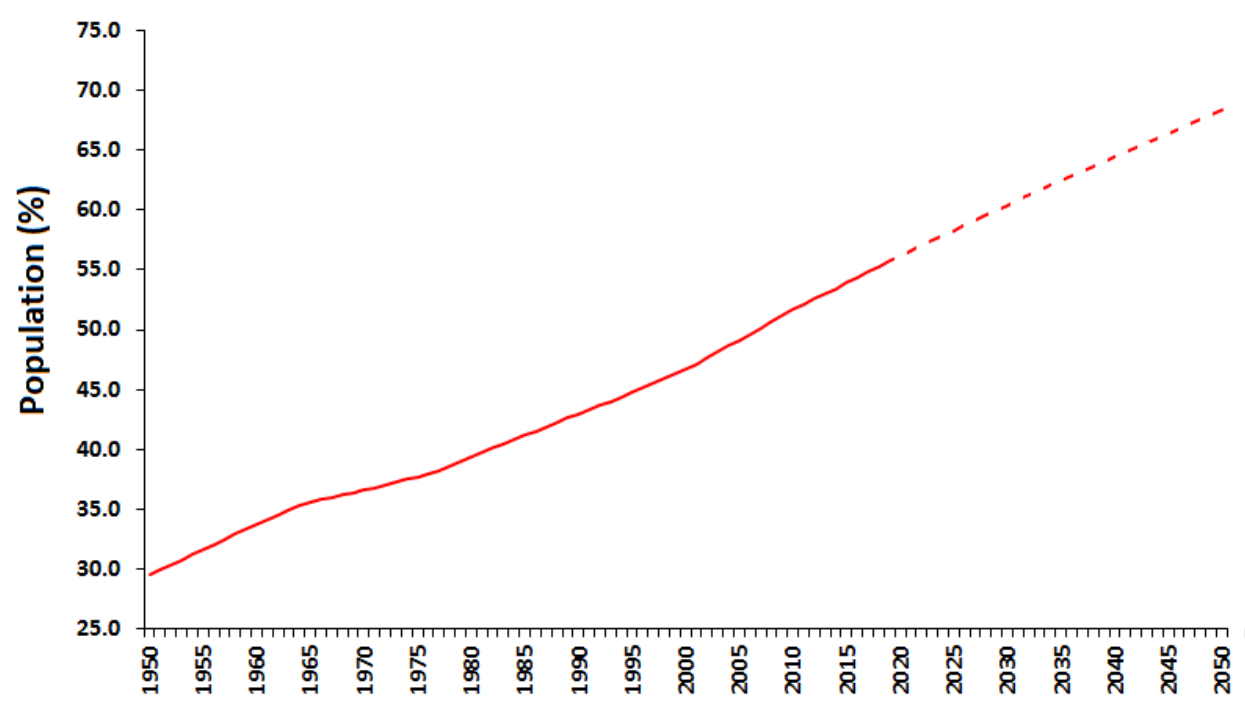

Fig. 2 Historical changes and future projection of global urban population (as percentage of total global population) (Source: World Bank, 2018)

It is estimated that $55 \%$ of the global population live in urban areas, although urban areas comprise only $3.6 \%$ of the total world land surface. About 274.7 thousand $\mathrm{km}^{2}$ of these urban areas accommodated 2.4 billion people in 1992, while 621.1 thousand $\mathrm{km}^{2}$ accommodated 4.0 billion people in 2016. This indicates that 346.4 thousand $\mathrm{km}^{2}$ of the global area has been converted to urban areas between 1992 and 2016 to accommodate the increase of 1.6 billion people (He et al., 2019). This increasing urbanization trend is the cause of ongoing environmental issues including biodiversity losses, environmental pollution and increased risks of hydro-metrological disasters, particularly urban floods (Müller et al. 2013; Shahid et al. 2016; Miller and Hutchins 2017).

Modelling projections indicate that the amount of land defined as urban will increase to between 1.2 and 3.1 million $\mathrm{km}^{2}$ in 2050 , accommodating $68 \%$ of the global population. The spatial extent of this urban area will be 1.6 to 3.6 times greater than in 2010 (Angel et al., 2011). This urbanization rate is essentially uncontrolled and not sustainable in many region (Dewan and Corner, 2014). Some data on the number of people globally affected by flooding, and some indicative figures on the costs of damage done, are shown in Fig. 3. This graphically shows the increase in economic impacts, and loss of life, over the last few decades. With an increasing population, these costs (both human and economic) will increase over time. 


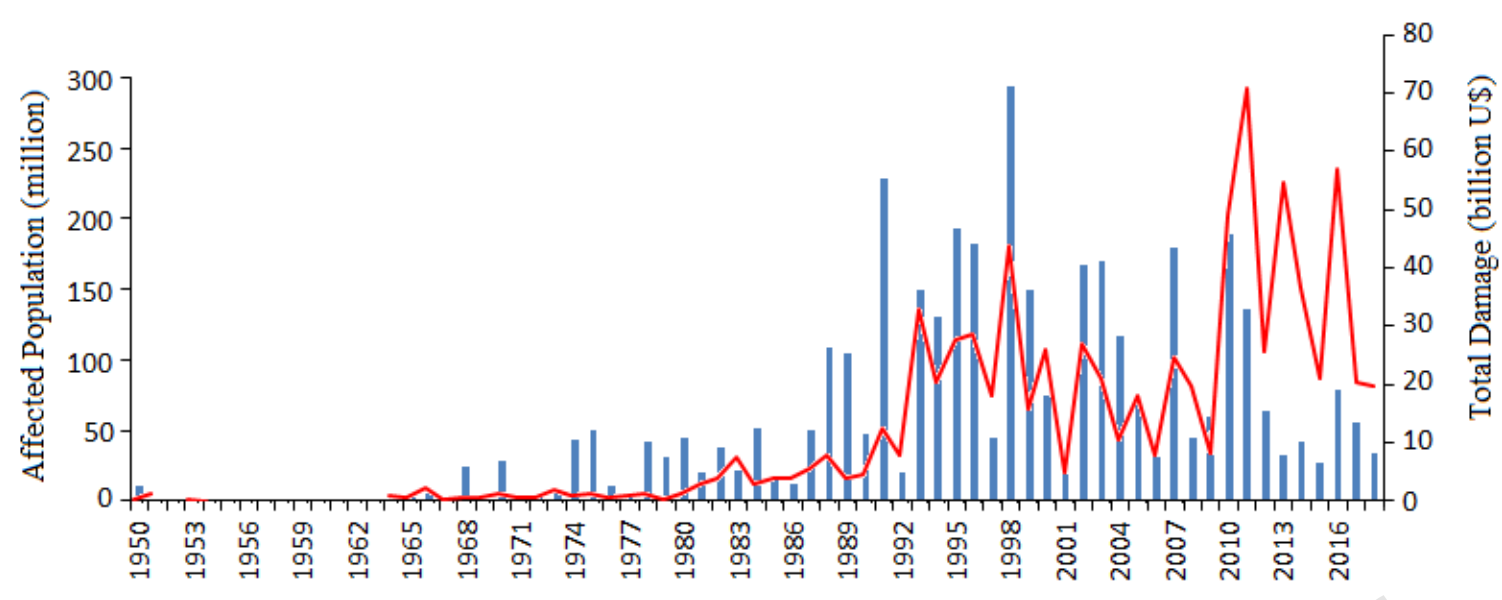

Fig. 3 Global population and economic impacts due to floods during 1950-2018 (source: EMDAT, 2019)

\subsection{Urban floods}

Floods can normally be divided into different types depending on their characteristics; specifically flash floods, riverine floods and tidal floods (Yevjevich 1994; Sayers et al. 2013). An intense rainfall event, particularly in an area with steep topography, results in a large volume of water accumulating in a limited area and then rapidly travelling downslope, resulting in the phenomenon known as a flash flood. Cities, or the areas of cities which are located in valleys or on the lower parts of hillslopes, are often affected by the fast-flowing water generated by these extreme rainfall events. The areal coverage and time span of a flash flood is usually not as great as a normal flood event (such as that caused by a natural river system), however the damage can be substantial due to the sudden occurrence and rapid movement of a large volume of water (Sene, 2013). In contrast, precipitation over a large area for an extended period of time causes an overflow and contributes to riverine floods. Cities located adjacent to large rivers often experience riverine floods, with flooding occurring over a large area, for an extended period of time (Vinet, 2018). The floods experienced by European cities due to the overflow of the Danube River after very heavy rain, are an example of riverine flooding. Coastal cities can also be affected by tidal floods resulting from cyclone and storm surges. The high waves usually also contain an enormous amount of energy and may often be devastating (Pan 2011; Karamouz and Zahmatkesh 2017). The tidal flood inundation level can be very high, and can fluctuate with tidal movements. Tidal flooding in the Miami Metropolitan Area on October 17, 2016 inundated a vast region, with floodwater up to 3 metres deep. 
All of the above-mentioned flood events can occur in an urban area. Urban floods, however, are considered a special type of flood that occurs due to an inadequate urban drainage system. A reduction in land previously available for water attenuation and infiltration means that most precipitation falling in urban areas will be required to drain away using the existing storm-water drainage systems which may have been designed to handle lower volumes of runoff water. Intense precipitation events can cause flooding when the amount of precipitation, and hence volume of water, exceeds the drainage capacity of the area. Rainwater starts depositing other than the drainage system and causes water to be stagnant in the low lying lands (Jegatheesan et al., 2019).

Urban floods block roads, inundate houses in low lying areas and disrupt the daily life of urban dwellers. Casualties from urban floods are usually not great, but structural and property damage, and economic losses, can be very high due to the population density of these areas, which usually also contain properties of high value and a high concentration of economic activity. For this reason, these urban floods are always more disastrous (Mohtar et al., 2020; Salimi and Al-Ghamdi, 2020). Some of the recent extreme rainfall-driven urban floods and their impacts are summarized in Table 1.

Table 1. A list of recent rainfall driven urban flood and their impacts

\begin{tabular}{lll}
\hline Date & $\begin{array}{l}\text { Infrastructure and population } \\
\text { Damage }\end{array}$ & Description \\
\hline
\end{tabular}

Sept 9, $2009 \quad$ More than 100 people died

Heavy rainfall caused a flash flood in Jeddah, Saudi Arabia

Jan 12, $2011 \quad$ Affected half million people and

Heavy rainfall caused worst flood in caused $\$ 879$ million economic losses Jakarta, Indonesia

July 21, 2012 Affected 1.6 million people and A rainfall driven flash flood hit caused an economic loss of $\$ 1.6$ Beijing, China billion

Oct 29, 2015 At least 58 people killed due to direct and indirect causes of flood

Heavy rainfall caused a flash flood in Baghdad, Iraq 
Nov 5, $2015 \quad 3$ people died

Jul 14, 2017 Disruption of urban activities

Aug 29, 2017 Confirmed death of 14 people

Nov 15, 2017 Caused significant damage to property and death of 24 people

Mar 21, 2018

Death of 3 people and displacement of thousands

May 27, $2018 \quad$ Huge losses in property and death of 1 person
A 30-minute long severe thunderstorm caused flash floods in Amman, Jordan

A 19-mm rainfall caused a flood in Moscow, Russia, even the city has an excellent drainage system

Heavy rain caused a flash flood in Mumbai, India which was called as one of the worst regional humanitarian crises by Red Cross

A heavy rainfall-driven flash flood occurred in Athens, Greece

A heavy rainstorm $(50 \mathrm{~mm})$ caused a flash flood event in São Paulo, Brazil

1000-year flash flood in Ellicott City, Maryland due to heavy rainfall (100 mm/hour), USA

Mar 1, 201920 people died and many houses collapsed

$97 \mathrm{~mm}$ rainfall in 30 hours caused a huge flash flood, Kandahar, Afghanistan

Jun 27, 2019 Death of 32 people and massive transport disruption

Heaviest one-day rainfall in a decade caused a severe flash flood in the city of Mumbai, India

\section{Climate change and urban floods}

Climate change impacts will generally differ between urbanized and non-urbanized areas.

Several studies have noted a higher increase in climatic extremes in cities compared to nonurbanized areas due to global warming. The following sections provide a brief review of literature related to climate change projections in urban regions and looks at potential increases in the intensity of urban floods. 


\subsection{Cities and climate change}

Urbanization causes a local change in land use and alteration of the microclimate (Freitag et al., 2018; Paul et al., 2018; Şimşek and Ödül, 2019). A localized alteration of climate due to urbanization, combined with changes due to global warming, means that the local climate of an urban area changes to a greater degree than the non-urbanized area (Shepherd et al. 2013; Liu and Niyogi 2019). Natural variability resulting from large-scale atmospheric phenomena is often magnified by the urban climate which can then influence the severity of these events. Various studies have reported alteration to rainfall patterns and humidity levels, as well as wind speed and direction, due to the effects of urbanization (Perryman and Dixon 2013; Ren 2015; Li et al. 2017b; Liu and Niyogi 2019). Studies have noted increased and more intense rainfall during the rainy months / wet seasons. Changnon (1979) and Landsberg (1981) reported increases in short-period, heavy precipitation in large cities. Dixon and Mote (2003) detailed an increase in rainfall frequency in Atlanta, in the United States, possibly due to an UHI effect. Several studies have reported an increased frequency of intense rainfall over large cities in China (Sun and Shu 2007; Yin et al. 2011; Yang et al. 2013; Song et al. 2014; Wang et al. 2017). An increase in intense rainfall events later in the evening in summer was observed in the megacity of Beijing (Liang et al., 2013; Yang et al. 2013). Liu and Niyogi (2019) conducted a review of 48 research papers dealing with the effect of urbanization on rainfall and reported a $2-18 \%$ increase in mean precipitation within $20-50 \mathrm{~km}$ of city centres. A review of the future projections of rainfall extremes in some major cities of the world is given in Table 2.

Table 2. Future projection of precipitation extremes in some major cities of the world

\begin{tabular}{|c|c|c|}
\hline Reference & City & Changes in rainfall extremes \\
\hline Cooper (2019) & Bangkok & $\begin{array}{l}\text { Extreme rainfall amount in different regions of } \\
\text { greater Bangkok will increase by } 80-120 \% \text { in the } \\
\text { latter part of the century }\end{array}$ \\
\hline Ali et al., (2014) & $\begin{array}{l}\text { Indian } \\
\text { cities }\end{array}$ & $\begin{array}{l}\text { One- to three-day duration maximum rainfall would } \\
\text { increase in major cities of India due to climate } \\
\text { change }\end{array}$ \\
\hline $\begin{array}{l}\text { DeGaetano and } \\
\text { Castellano (2017) }\end{array}$ & New York & $\begin{array}{l}\text { Median of } 100 \text {-year return period precipitation total } \\
\text { will increase by } 5-10 \% \text { during } 2010-2039 \text { and } 10- \\
20 \% \text { during } 2040-2069\end{array}$ \\
\hline $\begin{array}{l}\text { Webb and Hennessy } \\
\text { (2015) }\end{array}$ & Canberra & $\begin{array}{l}\text { Significant increase in rainfall intensities in the near } \\
\text { future }\end{array}$ \\
\hline
\end{tabular}




\begin{tabular}{lll}
\hline $\begin{array}{l}\text { Webb and Hennessy } \\
(2015)\end{array}$ & Melbourne & $\begin{array}{l}\text { Significant increase in daily rainfall intensity in } \\
\text { future }\end{array}$ \\
$\begin{array}{l}\text { Guerreiro et al. } \\
(2018)\end{array}$ & UK cities & $\begin{array}{l}\text { Increased flooding in eighty-five percent of UK } \\
\text { cities, including London. Fifty percent rise in peak } \\
\text { river flows in 2100 in 50\% of the UK cities }\end{array}$ \\
Wang et al. (2014) & $\begin{array}{l}\text { Ontario, } \\
\text { Canada }\end{array}$ & $\begin{array}{l}\text { Intensities of various duration rainfall events would } \\
\text { increase by 17\%, 22\% and 50\% in the 2030s, 2050s } \\
\text { and 2080s }\end{array}$ \\
$\begin{array}{l}\text { Mukherjee et al. } \\
\text { (2018) }\end{array}$ & $\begin{array}{l}\text { Indian } \\
\text { cities }\end{array}$ & $\begin{array}{l}10-30 \% \text { increase in 1-5 days precipitation maxima } \\
\text { at 5-500 years return period }\end{array}$
\end{tabular}

\subsection{Climate change impacts on urban floods}

Urban hydraulic structures are normally designed based on probable maximum flood (PMF) criteria; the largest flood that could conceivably occur at a particular location (WMO, 1985). The PMF is estimated from the possible maximum precipitation (PMP) that can occur at a location within a certain period of time, e.g. 1-hour maximum rainfall. The PMF is estimated from the maximum precipitation under the most favorable catchment conditions (e.g., maximum moisture) (Tetzlaff and Zimmer, 2013). Increasing rainfall extremes lead to increased maximum precipitation values and PMF. If urban hydraulic structures are not redesigned or retrofitted with design changes required to align with the recalculated PMF, the probability of urban flooding increases (Tetzlaff, 2009).

Studies have assessed the impact that climate change can have on urban floods in various cities around the world. A brief summary of these studies is presented in Table 3. 
Table 3. List of literature on the future projections of urban floods

\begin{tabular}{|c|c|c|}
\hline Reference & City & Changes in urban floods \\
\hline Suttles et al. (2018) & $\begin{array}{l}\text { Urban areas in the } \\
\text { southeast United } \\
\text { States }\end{array}$ & $\begin{array}{l}\text { 1-day and } 100 \text {-year floods will be nearly } \\
\text { doubled in future }\end{array}$ \\
\hline Akter et al. (2018) & $\begin{array}{l}\text { Urban floods in } \\
\text { Schijn River } \\
\text { Basin, Belgium }\end{array}$ & $\begin{array}{l}\text { The urban runoff will increase by } 200 \% \text { to } \\
500 \% \text { than existing flows }\end{array}$ \\
\hline Guo et al. (2018) & $\begin{array}{l}\text { Urban areas over } \\
\text { China }\end{array}$ & $\begin{array}{l}\text { More frequent urban floods due to a } 50 \% \\
\text { increase in precipitation in very wet days }\end{array}$ \\
\hline Markus et al. (2018) & $\begin{array}{l}\text { Cook County, } \\
\text { Illinois, USA }\end{array}$ & $\begin{array}{l}\text { More urban floods due to } 5-35 \% \text { increase in } \\
24 \text {-h } 100 \text {-year rainfall events }\end{array}$ \\
\hline $\begin{array}{l}\text { Guerreiro et al. } \\
\text { (2018) }\end{array}$ & $\begin{array}{l}\text { Floods in } 571 \\
\text { European cities }\end{array}$ & $\begin{array}{l}\text { Several cities will experience more than a } 50 \% \\
\text { increase in floods }\end{array}$ \\
\hline Zhao et al. (2016) & $\begin{array}{l}\text { Urban areas in San } \\
\text { Antonio River } \\
\text { Basin, USA }\end{array}$ & $\begin{array}{l}\text { Heavy flooding due to the increase in the } \\
\text { median of annual precipitation maximum up to } \\
885 \mathrm{~m}^{3} \mathrm{~s}^{-1}\end{array}$ \\
\hline $\begin{array}{l}\text { Supharatid et al. } \\
\text { (2016) }\end{array}$ & $\begin{array}{l}\text { Bangkok, } \\
\text { Thailand }\end{array}$ & $\begin{array}{l}\text { Increased vulnerability to floods due to the } \\
\text { increase in peak rainfall by } 100 \%\end{array}$ \\
\hline $\begin{array}{l}\text { Anandhi et al. } \\
(2016)\end{array}$ & South Asian cities & $\begin{array}{l}\text { Increased temperature by } 0.8 \text { to } 2.1 \% \text { will } \\
\text { cause more urban floods due to melting of the } \\
\text { glaciers in the Himalaya }\end{array}$ \\
\hline $\begin{array}{l}\text { Cabrera and Lee } \\
\text { (2018) }\end{array}$ & $\begin{array}{l}\text { Davao Oriental, } \\
\text { Philippines }\end{array}$ & $\begin{array}{l}\text { Higher flood magnitude due to a } 69 \% \text { increase } \\
\text { in rainfall intensity }\end{array}$ \\
\hline $\begin{array}{l}\text { Bajracharya et al. } \\
\text { (2018) }\end{array}$ & $\begin{array}{l}\text { Kaligandaki } \\
\text { Basin, Nepal }\end{array}$ & $\begin{array}{l}\text { A } 50 \% \text { increase in peak floods due to glacier } \\
\text { melting under higher temperature }\end{array}$ \\
\hline $\begin{array}{l}\text { Byun and Hamlet } \\
\text { (2018) }\end{array}$ & $\begin{array}{l}\text { Midwest and } \\
\text { Great Lakes } \\
\text { region, USA }\end{array}$ & $\begin{array}{l}\text { Increased frequency of flooding and } \\
\text { stormwater events due to a } 30 \% \text { increase in } \\
\text { precipitation }\end{array}$ \\
\hline Alfieri et al. (2015) & European cities & $\begin{array}{l}\text { A } 100 \% \text { increase in } 100 \text {-year or above flood } \\
\text { peaks }\end{array}$ \\
\hline $\begin{array}{l}\text { Poelmans et al. } \\
\text { (2011) }\end{array}$ & $\begin{array}{l}\text { Molenbeek } \\
\text { catchment, } \\
\text { Belgium }\end{array}$ & $\begin{array}{l}\text { Increase in the flood-affected area by } 0.1 \text { to } 7 \\
\text { ha. For a } 100 \text {-year return period flood event }\end{array}$ \\
\hline $\begin{array}{l}\text { Zahmatkesh et al. } \\
(2014)\end{array}$ & $\begin{array}{l}\text { Urbanized Bronx } \\
\text { River watershed, } \\
\text { USA }\end{array}$ & $\begin{array}{l}\text { Increase in runoff volume up to } 40 \% \text { and thus, } \\
\text { more floods }\end{array}$ \\
\hline Mishra et al. (2018) & $\begin{array}{l}\text { Ciliwung River } \\
\text { Basin, Jakarta, } \\
\text { Indonesia }\end{array}$ & $\begin{array}{l}\text { Increasing flood inundation areas and depths } \\
\text { ranging from } 6 \% \text { to } 31 \%\end{array}$ \\
\hline $\begin{array}{l}\text { Januriyadi et al. } \\
(2018)\end{array}$ & Jakarta, Indonesia & $\begin{array}{l}322-402 \% \text { increase in flood risk in } 2050 \text { at a } \\
\text { significance level of } 0.05\end{array}$ \\
\hline
\end{tabular}




\begin{tabular}{lll}
\hline $\begin{array}{l}\text { Hettiarachchi et al. } \\
(2018)\end{array}$ & $\begin{array}{l}\text { South Washington } \\
\text { Watershed }\end{array}$ & $\begin{array}{l}10-170 \% \text { increase in flood risk with } \\
\text { confidence }\end{array}$ \\
& District, USA &
\end{tabular}

Some studies have indicated the potential for an increase in flood peaks and associated return periods in urban areas. The increase in flooding can be due to both land use changes as a result of urbanization, and increases in extreme rainfall events due to climate change. The relative impacts will depend on sustainability in urban development. Contribution of urbanization to flood peak and frequency will be higher for unsustainable cities. The studies revealed a possible large increase in future urban floods. Projected increases in flood risk is high for many cities (Januriyadi et al. 2018; Akter et al. 2018). Flood peaks will also double in many European cities (Alfieri et al., 2015). One issue in mitigating urban flood risk is the inherent uncertainty related to flood projections. With increases in peak urban floods projected to be two to five times that of current peaks in many cities, this will be a major challenge for decision-makers when designing urban storm water management system (SWMS).

\section{Limitations of conventional SWMS for climate-change-induced flood mitigation}

A SWMS is considered a vital component of any city. The system operates by draining excess storm water to the nearest water body and is also used to manage the flooding event itself (Mikkelsen, 2004). Stormwater management systems replace the natural drainage of a catchment by using channels and pipes to efficiently transport rainwater runoff away from the urban areas and therefore prevent flooding of low-lying regions (Wu et al., 2019). Those areas with an efficient SWMS tend to be at low risk of flooding. An efficient SWMS also assists in maintaining the natural hydrologic cycle, prevents unacceptable stream and soil erosion, and protects water quality.

Retrofitting an existing SWMS is often suggested as a method for controlling climatechange-induced flooding (Nguyen et al., 2019). This involves the alteration of an existing SWMS to meet design criteria which have been revised in order to handle increased flood peaks or to take account of new policies and guidelines (Mikkelsen 2004; Schwartz et al. 2017). The retrofitting of any infrastructure is inherently a difficult and expensive task, but this is often required to accommodate future climate change impacts (Hulley et al., 2008). It has recently has been suggested that possible climate change impacts be incorporated into the 
SWMS design criteria so that the construction of a new SWMS or replacement of an existing SWMS during urban expansions can include these updated criteria.

A SWMS is generally designed to handle runoff from a 10 to 20 year return period extreme rainfall event. It normally does not consider any changes to the land-use and associated landcover of the catchment area in which it is located (Hirsch and Ryberg, 2012; Noor et al. 2018). Urban development, however, is a continuous process which leads to modified land use and an increased amount of paved (ie. impervious) surface. This increases the surface runoff volume and can exceed the design capacity of the SWMS. In this case, retrofitting of the SWMS may be required, based on revised design criteria (including return periods) which take account of the new catchment characteristics (Hulley et al., 2008).

Another major disadvantage of a conventional SWMS is that they are designed based on the concept of a stationery climate; that rainfall variation over time is not significant (Nashwan et al., 2019). However, various factors can impact the climate cycle and result in a significant deviation in mean rainfall values over time (Noor et al., 2018). Designing a SWMS to consider the rainfall distribution function as time-variant is one option, as modelling indicates that the future variability in rainfall will not follow historical trends. Record-breaking extreme rainfall events and associated devastating floods have been recorded in many cities in recent decades, all ascribed to global warming-driven climate change (Khan et al., 2019; Salman et al., 2018). Therefore designing a SWMS assuming a non-stationary climate may also fail.

The basic cost assumption which is usually made when designing a SWMS to mitigate an urban flooding event, is that the construction cost should be less than the damage which could result from any floods in the absence of any mitigation measures (Visitacion et al., 2009). The cost of the SWMS should therefore be considered for different climate change scenarios and uncertainty associated with them (Weiss et al., 2005). Striking a balance between environmental factors and economic factors is important (Xu et al. 2017; Xie et al., 2019). Dong et al. (2017) argued that most conventional SWMS are limited to flood intensity, and uncertainty in regards to future climate change scenarios is usually not considered. Uncertainty does exist in all climate change projections where natural variability in climate impact short-term projections and greenhouse gas emission scenarios are the major contributor to long-term climate projections (Latif, 2013). Uncertainty regarding future rainfall trends due to climate change and urbanization may impact the future water management capability of a conventional SWMS (Dong et al., 2018). 


\section{LID in flood mitigation}

\subsection{An overview of LID techniques}

LID tools are devised to preserve the natural hydrological behavior of watersheds, e.g., transpiration, retention and seepage, in order to reduce the damaging effect of increased water runoff resulting from urbanization. LID practices, regarded as 'near-nature' concepts, can mitigate the negative effect of climate change on urban flooding (Goncalves et al., 2018; Sage et al., 2015; Zhu et al., 2019). LID practices include rain barrels, rain gardens (Palla et al. 2008), porous surfaces (Huang et al., 2016; Kamali et al., 2017), infiltration trenches, bioretention cells (Zhang and Chui, 2018; Yang and Chui 2018), bio-retention swales, bioretention ponds, etc. (Barbosa et al., 2012; Eckart et al., 2017; Elliott and Trowsdale, 2007; Qin et al., 2013; Randhir and Raposa, 2014; Zhu and Chen, 2017). A summary of the most commonly used LID tools is described in Table 4.

Table 4. Description of most commonly used and effective low impact development tools

\begin{tabular}{|c|c|c|}
\hline LID tool & Acronym & Description \\
\hline Green parking & $\mathrm{RP}$ & $\begin{array}{l}\text { A combination of approaches used to reduce parking area ar } \\
\text { its perviousness for lowering runoff amount }\end{array}$ \\
\hline $\begin{array}{l}\text { Green roof or } \\
\text { eco-roof }\end{array}$ & GR & $\begin{array}{l}\text { Vegetation planted on waterproof membrane on rooftop to } \\
\text { provide rainwater buffer and reduction of runoff }\end{array}$ \\
\hline Rain garden & RG & $\begin{array}{l}\text { A vegetated concave with urban landscape designed to store } \\
\text { and infiltrate stormwater }\end{array}$ \\
\hline $\begin{array}{l}\text { Bioretention } \\
\text { pond/cell }\end{array}$ & BRC & $\begin{array}{l}\text { Same as rain garden with some hydraulic structures to enhar } \\
\text { storage and subsurface percolation }\end{array}$ \\
\hline $\begin{array}{l}\text { Bioretention } \\
\text { swales or green } \\
\text { swales }\end{array}$ & SW & $\begin{array}{l}\text { Shallow grassed or vegetated channels with side slopes and } \\
\text { bottom used for runoff water collection and movement }\end{array}$ \\
\hline $\begin{array}{l}\text { Filter strips/ } \\
\text { vegetated } \\
\text { swales }\end{array}$ & VS & $\begin{array}{l}\text { A long-vegetated ditch designed to slowdown the runoff rat } \\
\text { and enhance infiltration }\end{array}$ \\
\hline $\begin{array}{l}\text { Steam } \\
\text { Naturalization }\end{array}$ & $\mathrm{SN}$ & $\begin{array}{l}\text { A process of vegetation of riverbed to reduce flow rate and } \\
\text { enhance infiltration }\end{array}$ \\
\hline $\begin{array}{l}\text { Porous } \\
\text { Pavements }\end{array}$ & PV & $\begin{array}{l}\text { A permeable surface (e.g., pervious concrete, permeable } \\
\text { asphalt) to allow subsoil infiltration of surface runoff }\end{array}$ \\
\hline $\begin{array}{l}\text { Infiltration } \\
\text { trench }\end{array}$ & IT & $\begin{array}{l}\text { Shallow concaves with highly permeable soils used for } \\
\text { temporary storage of runoff and quick subsurface seepage }\end{array}$ \\
\hline
\end{tabular}


Detention $\quad \mathrm{DP} / \mathrm{RH} \quad$ An artificial depression in urban landscape to hold stormwater pond/Rainwater runoff for a longer period

Harvesting

Retention pond RP

An artificial depression to collect and gradually release runoff water to drainage system.

Retention tank

Rain barrel $\quad$ RB

Small surface tank for collection of rainwater from rooftop drainpipes

Cisterns $\quad$ CS Large subsurface reservoir for storage of surface runoff

Tree boxes TB Small bioretention cell placed underneath trees to collect runoff

\subsection{Effectiveness of Different LIDs in Flood Mitigation}

The hydrological performance of LIDs has been assessed in work conducted in various climate regions (Recanatesi et al. 2017; Chang et al. 2018; Joyce et al. 2018; Scholz and Grabowiecki 2007; Berndtsson 2010; Ghisi et al. 2012). Literature related to the use of LID practices to mitigate urban floods is briefly reviewed in this section. Table 5 presents LID practices used in a number of cities and provides an indication of their success in the reduction of flood peak and volume.

Table 5. Summary of the studies on the effectiveness of LID practices in the reduction of flood peak and volume

\begin{tabular}{|c|c|c|}
\hline $\begin{array}{ll}\text { Reference } & \text { LID }\end{array}$ & City/Country & Impact \\
\hline Li et al., (2019) DP & SA city, China & $\begin{array}{l}\text { Nearly } 92 \% \text { reduction of } \\
\text { peak flowrate }\end{array}$ \\
\hline $\begin{array}{l}\text { Palermo et al., PV, GR } \\
\text { (2020b) }\end{array}$ & Paola, Italy & $\begin{array}{l}\text { Runoff and peak flowrate } \\
\text { reduction up to } 45.8 \% \text { and } \\
54.3 \% \text { respectively }\end{array}$ \\
\hline $\begin{array}{l}\text { Chen et al., Coupled PV } \\
(2020)\end{array}$ & Jinan, China & $\begin{array}{l}\text { Reduction of runoff } \\
\text { amount by } 46.09 \% \text { and } \\
\text { peak flow rate by } 11.45 \%\end{array}$ \\
\hline 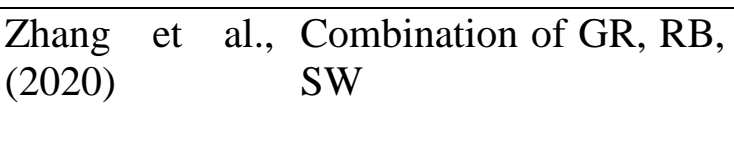 & $\begin{array}{l}\text { Beijing, } \\
\text { China }\end{array}$ & $\begin{array}{l}\text { Reduction of runoff } \\
\text { volume by } 48.59 \% \text { peak } \\
\text { flow rate } 67.29 \%\end{array}$ \\
\hline Du et al. (2019) RG & $\begin{array}{l}\text { Central } \\
\text { Shanghai, }\end{array}$ & $\begin{array}{l}\text { Reduction of flood volume } \\
\text { by } 23.6-98.4 \% \text {, inundation } \\
\text { extents by } 26.1-82.4 \% \text { and }\end{array}$ \\
\hline
\end{tabular}




\begin{tabular}{|c|c|c|}
\hline & China & flood depth of $0.1-0.2 \mathrm{~m}$ \\
\hline $\begin{array}{l}\text { Ghodsi et al. VS, BRC, PV, IT } \\
(2020)\end{array}$ & $\begin{array}{l}\text { Northeastern } \\
\text { Tehran, Iran }\end{array}$ & $\begin{array}{l}\text { Reduction of flood volume } \\
\text { up to } 18 \%\end{array}$ \\
\hline $\begin{array}{ll}\text { Goncalves et al. } & \text { RG, IT, DP, DP+ RG, } \\
\text { (2018) } & \text { DP+ IT }\end{array}$ & $\begin{array}{l}\text { Joinville, } \\
\text { South Brazil }\end{array}$ & $\begin{array}{l}\text { Reduction of total flood } \\
\text { volume between } 30 \% \text { and } \\
75 \% . \text { Integration of } \\
\text { centralized and } \\
\text { decentralized LIDs can } \\
\text { provide the best reduction } \\
\text { of flood volume }\end{array}$ \\
\hline Hu et al. (2018) Different types of PV & $\begin{array}{l}\text { Nanjing, } \\
\text { China }\end{array}$ & $\begin{array}{l}\text { PV reduces flood volume } \\
\text { by } 1-40 \% \text { and flood peak } \\
\text { by } 7-43 \%\end{array}$ \\
\hline $\begin{array}{l}\text { Eckart et al. } \\
\text { (2018) }\end{array}$ & $\begin{array}{l}\text { Ontario, } \\
\text { Canada }\end{array}$ & $\begin{array}{l}\text { IT is the most cost- } \\
\text { effective LID in the } \\
\text { reduction of flood peak }\end{array}$ \\
\hline $\begin{array}{l}\text { Wu et al. } \\
\text { (2018) }\end{array}$ & $\begin{array}{l}\text { Shenzhen \& } \\
\text { Guangdong, } \\
\text { China }\end{array}$ & $\begin{array}{l}\text { PV and GR can reduce } \\
\text { flood depth by } 3-29 \% \text {; } \\
\text { flood coverage by } 7-55 \% \text {, } \\
\text { and flood duration by } 0- \\
43 \%\end{array}$ \\
\hline $\begin{array}{l}\text { Zhu et al. } \\
\text { (2019) }\end{array}$ & $\begin{array}{l}\text { Guangzhou, } \\
\text { China }\end{array}$ & $\begin{array}{l}\text { PV and BRC can control } \\
\text { flood volume. Limited PV } \\
\text { coverage can have a } \\
\text { significant effect on flood } \\
\text { volume }\end{array}$ \\
\hline $\begin{array}{l}\text { PV, BRC, IT, RB, VS, } \\
\text { GR, TB }\end{array}$ & $\begin{array}{l}\text { Taipei, } \\
\text { Taiwan }\end{array}$ & $\begin{array}{l}\text { Reduce flood peak and } \\
\text { timing in the range of } \\
5.75-29.80 \% \text { and } 12.50- \\
20 \% \text {, respectively at local; } \\
\text { and } 9.52 \%-23.49 \% \text { and } \\
12.50 \%-37.5 \% \text { at the sub- } \\
\text { catchment scales }\end{array}$ \\
\hline Hu et al. (2017) RH, PV & $\begin{array}{l}\text { Nanjing, } \\
\text { China }\end{array}$ & $\begin{array}{l}\text { Reduce flood inundation } \\
\text { areas by } 2-17 \% \text { and flood } \\
\text { hazard level by } 6-80 \%\end{array}$ \\
\hline Juan et al. 2017 RB, SW, GR, RG & $\begin{array}{l}\text { Houston, } \\
\text { Texas, } \\
\text { USA }\end{array}$ & $\begin{array}{l}\text { Varying degrees of } \\
\text { reduction in peak discharge } \\
\text { and runoff volume }\end{array}$ \\
\hline $\begin{array}{l}\text { Kong et al. } \\
2017\end{array}$ & $\begin{array}{l}\text { Bazhong, } \\
\text { China }\end{array}$ & $\begin{array}{l}\text { LIDs contribute to a } \\
\text { significant reduction of } \\
\text { flood }\end{array}$ \\
\hline Li et al. 2017a BRC, RB, SW, GR, PV & Xi'an, China & $\begin{array}{l}\text { The effectiveness of LIDs } \\
\text { in mitigating floods can be }\end{array}$ \\
\hline
\end{tabular}


ordered as $\mathrm{BRC}>\mathrm{RB}>$ $\mathrm{SW}>\mathrm{GR}>\mathrm{PV}$. BRC and

GR are the optimal LID combination

\begin{tabular}{|c|c|c|c|}
\hline $\begin{array}{l}\text { Ahmed et al. } \\
2017\end{array}$ & IT & $\begin{array}{l}\text { Johor, } \\
\text { Malaysia }\end{array}$ & $\begin{array}{l}\text { LID can reduce pick flow } \\
\text { in the range of } 17.5 \% \text { to } \\
20.95 \%\end{array}$ \\
\hline $\begin{array}{l}\text { Zhu and Chen, } \\
\text { (2017) }\end{array}$ & $\begin{array}{l}\text { BRC, PV, IT, RB, VS, } \\
\text { RG and GR }\end{array}$ & $\begin{array}{l}\text { Guangzhou, } \\
\text { China }\end{array}$ & $\begin{array}{l}\text { LIDs are effective in future } \\
\text { flood reduction due to the } \\
\text { increase in rainfall } \\
\text { intensity, duration or peak }\end{array}$ \\
\hline $\begin{array}{l}\text { Tredway and } \\
\text { Havlick (2017) }\end{array}$ & $\mathrm{PV}, \mathrm{RG}, \mathrm{SN}$ & $\begin{array}{l}\text { Colorado, } \\
\text { USA }\end{array}$ & $\begin{array}{l}\text { Reduction of runoff by } \\
18.8 \% \text { using the PV, } 4.7 \% \\
\text { using RG, } 12.3 \% \text { using SN } \\
\text { and } 32.7 \% \text { using a } \\
\text { combination of the LIDs }\end{array}$ \\
\hline $\begin{array}{l}\text { Ahiablame and } \\
\text { Shakya (2016) }\end{array}$ & $\mathrm{PV}, \mathrm{RG}, \mathrm{RB}$ & $\begin{array}{l}\text { Central } \\
\text { Illinois, USA }\end{array}$ & $3-47 \%$ reduction of runoff \\
\hline $\begin{array}{l}\text { Shannak et al. } \\
\text { (2014) }\end{array}$ & RH & $\begin{array}{l}\text { Dallas, } \\
\text { USA }\end{array}$ & $\begin{array}{l}\text { Total runoff reduction by } \\
45 \%\end{array}$ \\
\hline $\begin{array}{l}\text { Lee et al. } \\
\text { (2013) }\end{array}$ & IT, VS, GR, PV & South Korea & $\begin{array}{l}\text { Peak runoff was reduced } \\
\text { by } 6-16 \%\end{array}$ \\
\hline $\begin{array}{l}\text { Qin et al. } \\
\text { (2013) }\end{array}$ & SW, PV, GR & $\begin{array}{l}\text { Shenzhen, } \\
\text { China }\end{array}$ & $\begin{array}{l}\text { Reduce peak runoff } \\
\text { effectively }\end{array}$ \\
\hline $\begin{array}{l}\text { Alfredo et al. } \\
\text { (2010) }\end{array}$ & GR & $\begin{array}{l}\text { New York } \\
\text { City, USA }\end{array}$ & $\begin{array}{l}\text { Decrease } 30-78 \% \text { of peak } \\
\text { flow }\end{array}$ \\
\hline $\begin{array}{l}\text { Dreelin et al. } \\
(2006)\end{array}$ & PV parking & $\begin{array}{l}\text { Athens, } \\
\text { Georgia, USA }\end{array}$ & $\begin{array}{l}\text { PV parking can reduce } \\
\text { flood volume by } 93 \% \\
\text { compared to asphalt } \\
\text { parking }\end{array}$ \\
\hline $\begin{array}{l}\text { Ahiablame et } \\
\text { al. (2013) }\end{array}$ & $\mathrm{RB}, \mathrm{PV}$ & $\begin{array}{l}\text { Indianapolis, } \\
\text { USA }\end{array}$ & $\begin{array}{l}\text { Reduce flood volume by } \\
2-12 \%\end{array}$ \\
\hline Hu et al. (2017) & $\mathrm{PV}, \mathrm{RH}$ & Nanjing, China & $\begin{array}{l}\text { Decrease flood inundation } \\
\text { areas by } 2-17 \% \text { and flood } \\
\text { risk area by } 60-80 \%\end{array}$ \\
\hline $\begin{array}{l}\text { Zhang et al., } \\
\text { (2016) }\end{array}$ & RH & Nanjing, China & $\begin{array}{l}\text { Reduce flood volume by } \\
0.6-36.8 \%\end{array}$ \\
\hline $\begin{array}{l}\text { Schmitter et al. } \\
(2016)\end{array}$ & GR & Singapore & $\begin{array}{l}\text { Significant positive } \\
\text { impacts on flood protection }\end{array}$ \\
\hline $\begin{array}{l}\text { Son et al. } \\
\text { (2017) }\end{array}$ & Various LIDs & $\begin{array}{l}\text { Cheongju City, } \\
\text { Republic of }\end{array}$ & $\begin{array}{l}\text { Reduce the effect of } \\
\text { torrential downpours in }\end{array}$ \\
\hline
\end{tabular}




\begin{tabular}{llll}
\hline & Korea & extreme summer \\
\hline $\begin{array}{l}\text { Sun et al. } \\
(2014)\end{array}$ & PV & Lenexa, USA & $\begin{array}{l}\text { Highly effective for small } \\
\text { rainfall events }\end{array}$ \\
\hline
\end{tabular}

The performance of LIDs in flood mitigation has been evaluated at a number of different scales. These studies indicate that site-specific LIDs can be a substitute for a traditional SWMS. LIDs can be effective even under unfavorable conditions and circumstances, including unsatisfactory performance due to high groundwater level, unexpected storm characteristics, and the seasonal variations in rainfall extremes (Palanisamy and Chui 2015; Jackisch and Weiler 2017). Studies reveal that LIDs can also be used for flood reduction at the scale of a watershed (Palla and Gnecco, 2015; Zhang and Hu, 2014). The use of LIDs can significantly change the hydrological cycle and reduce flood volume for the same rainfall intensity when compared to the same event in the absence of any LID installations (Gilroy and McCuen 2009; Qin et al. 2013; Walsh et al. 2014; Liu et al. 2015; Zhu and Chen 2017; Son et al. 2017). Using small-scale LID installations tends to be more cost-effective than using large-scale LIDs (Walsh et al., 2014).

Studies have been conducted to evaluate the effect of LIDs on a wide range of climatic and geographical regions; from the humid, tropical climate found on the equator, to arid and cold mountainous regions. The effectiveness of different LIDs was found to vary according to the specific environment. Overall, the porous surfaces were more effective in reducing flood peaks resulting from short duration rainfall events, while bioretention cells were more effective in reducing flood peaks from the longer duration rainfall events.

Space limitation is normally the major problem in the implementation of LIDs in denser urban areas. If implemented successfully, however, they can effectively reduce flood volume. A study in Nanjing (China) showed that LID implementation reduced total flood volumes by up to $36.8 \%$ (Zhang et al., 2016). Most LID studies have been focused on the reduction of flood peaks and volume, however a few studies have also looked at the ability of LIDs to reduce the amount of area inundated by flooding, and have shown the effectiveness of LIDs in reducing inundation depth and area affected (Hu et al., 2017).

LIDs can be adjusted in response to climate change, and can thus be more efficient in mitigating floods due to climate change when compared to conventional flood management systems (Zhou et al., 2018). Studies have indicated that if LIDs are designed to take account 
of rainfall characteristics projected for future climate change scenarios, they can effectively reduce urban flooding resulting from a changing climate. Several studies have pointed out some challenges (Shafique and Kim, 2017; Hewitt et al., 2019; Sohn et al., 2019; Hua et al., 2019). Other studies have indicated that while LIDs are effective for small rainfall events, they are less able to control floods resulting from extreme rainfall occurrences (Sun et al., 2014).

The combined use of different LID practices, and optimization of specific LID parameters particular to the physical environment where the LID is being implemented, can improve the effectiveness of the mitigation provided. A brief review of literature related to the integration of LIDs and optimization of LID parameters is provided in the following subsections.

\subsection{Performance Improvement through Combination of LIDs}

A combination of different LIDs, with differing characteristics, may provide the best overall performance (Lim and Lu 2016; Silva and Costa 2016; Ahiablame and Shakya 2016). Ahiablame and Shakya (2016) showed that the use of individual LIDs in isolation could reduce annual flood volumes by $3-40 \%$, while a combination of different LID methods could reduce annual flood volumes by 16-47\%. Liu et al. (2015) assessed the performance of different combinations of LIDs and reported that an optimum combination of LIDs could reduce flood volumes by $26.47 \%$. A number of studies have also attempted to determine the optimal combination of different LIDs, including green roofs, porous surface, bio-retention cells and other LIDs (Du et al., 2015; Huang et al., 2015; Jia et al., 2012). Chaosakul et al. (2013) explored the use of single and multiple combinations of LIDs in the reduction of floods in a peri-urban area near Bangkok, and illustrated the advantages of using an integrated LID system in reducing stormwater amount. They also found that a combination of two LIDs (a rain barrel and a bioretention cell) is more effective in the reduction of flood volume than the individual LID. Baek et al. (2015) analyzed the performance of a combination of six LIDs in mitigating flooding in a commercial site in Korea and summarized the improvement in performance.

The optimum LID combination differed between regions due to differing climatic and physical regional characteristics (Chaosakul et al. 2013; Huang et al. 2015; Baek et al. 2015). It is evident that area or catchment specific studies are required to select the combination of LIDs which most effectively control flood events. 


\subsection{Optimization of LID parameters for flood mitigation}

Optimization of LID parameters can improve the performance of LIDs, however studies related to the optimization of design parameters of LIDs, particularly in developing countries, are limited (Eckart et al., 2017, 2018; Liu et al., 2015; Zhu and Chen, 2017; Wang et al., 2020). Few studies have been conducted on optimization of LID design parameters such as sub-catchment properties, storage depth or drain offset height (Qin et al. 2013; Rossman 2010). Stormwater models, or a combination of stormwater model and optimization model, are normally used for this purpose. A large number of models have previously been used to evaluate the hydrological effects of LID and the optimization of LID parameters (Baek et al., 2015; Chui et al., 2016; Duan et al., 2016; Elliott and Trowsdale, 2007; Morsy et al., 2016; Trinh and Chui, 2013). One common tool usually used for rainfall-runoff modelling, the Storm Water Management Model (SWMM) (Rossman and Huber, 2015), is also often used for the optimization of LID parameters (Goncalves et al., 2018; Palla et al., 2008). Bacchin et al. (2014) integrated the ArcGIS (ESRI, 2011) and SWMM to assist in an evaluation of the spatial organization of LIDs within the Brazilian city of Porto Alegre. Palla et al. (2008) studied the hydrological effects of green roof implementation (at the catchment scale) in Genoa, Italy, and showed that optimizing the LID parameters used can significantly reduce the flood peak. Zischg et al. (2017) assessed the performance of different configurations of LIDs in the reduction of a flood peak in Kiruna city, Sweden and emphasized the importance of optimizing the LID parameters. Zhu et al. (2019) used a model-independent parameter estimation tool (PEST) (Doherty, 2010) for the auto-calibration of LID parameters (based on SWMM) in China, and showed that these calibrated LIDs can simulate runoff processes with a high degree of reliability. Eckart et al. (2018) integrated a SWMM with a multi-objective evolutionary algorithm to optimize LID parameters in a watershed in Windsor, Ontario. This study showed that optimized LIDs can reduce flood peaks by $29 \%$ and flood volume by $13 \%$. Ghodsi et al. (2020) proposed that optimization of LID design parameter using projected rainfall under climate change scenarios can be used for the reduction of climate-changeinduced urban floods.

Several studies also attempted the mathematical optimization of LID layouts and practices for the enhancement of LID performance and reduction of implementation cost. Men et al., (2020) optimized the layout design of LIDs in Ximen, Pingxiang, China using preference-inspired, co-evolutionary algorithm using goal vectors (PICEA-g) (Wang et al., 2013) and improved the runoff reduction by 21.8\%. Bahrami et al., (2019) developed a simulation-optimization model and LID implementation cost in Tehran, Iran can be reduced 
by $45 \%$ through optimization of LID layout. Palermo et al., (2020a) optimized LID practices through a joint use of a decision-making tool and Rough set method to decide the optimal rainwater reuse for reduction of runoff. Tsai et al., (2019) used genetic algorithm for optimization of cost-effectiveness tradeoff of LID practices in New Taipei, Taiwan. Oberascher et al., (2019) assessed the performance of smart rain barrel through optimization of its installation site in Innsbruck (Austria) and reported a reduction of flood volume by 18$40 \%$ depending on the installation site. Chen et al., (2015) attempted to find an optimized combination of different LID practices in a construction site of Beijing and showed a $36 \%$ reduction of peak flow is possible through optimization of LID layout. Guoshun et al., (2013) used a multi-objective optimization method for finding a cost-effective LID implementation design in Fox Hollow Watershed of Pennsylvania and showed that an $11 \%$ reduction of peak flow is possible through LID layout optimization. Zeng et al., (2020) used analytical probabilistic method for optimization of LID framework for maximizing cost-effectiveness and remarked that such optimization can help decision-maker to choose the appropriate LIDs for implementation.

Though the effectiveness of LIDs can be improved significantly through optimization of LID parameters, this parameter information is still very limited for most developing countries. In many cases design guidelines from developed countries are used, however these guidelines may not be suitable when used in less developed countries and, as a consequence, the results may not be optimal.

\subsection{LIDs for adaptation to climate change uncertainties}

The focus of recent scientific research on climate change adaptation policies is to ensure that urban stormwater management systems are less susceptible to climate-related impacts, while also addressing the problems facing the implementation of sustainable urban development designs (Ramyar et al., 2019; Serre and Heinzlef, 2018). Future changes in climate and land use will modify the characteristics of surface runoff and potentially increase the probability of failure of critical infrastructures designed to manage surface water (Mallakpour et al., 2019). Regular retrofitting of conventional SWMS can mitigate the possible climate change impacts. The uncertainty inherent in current climate projections, however, is still a major challenge.

The impacts of climate changes in urban areas would be more severe with a high level of uncertainty (Januriyadi et al. 2018; Hettiarachchi et al. 2018; Akter et al. 2018). The retrofitting of existing urban SWMS capable of handling storm events which may or may not 
occur, is not cost-effective. The retrofitting of an existing SWMS, or design of a new SWMS, is usually accomplished through optimization of the upfront and ongoing cost and the predicted flood reduction capability, based on climate model projections (Zhan and Chui 2016; Eckart et al. 2018; Huang et al. 2018). Using LID methods to increase the amount of available permeable surface can effectively reduce flood peaks and volume by increasing water percolation capacity and therefore allowing the storage of water within the sub-surface (Barbosa et al., 2012; Dietz, 2007; Eckart et al., 2018; Zhu and Chen, 2017). These methods can be used, in association with a conventional SWMS, to handle the uncertainty inherent in climate projections. If a higher level of flooding occurs, the number and type of LIDs can be increased to manage the situation, instead of requiring costly retrofitting of the SWMS.

LID practices attempt to conserve pre-urban hydrological cycle (Chang 2010; Hamel et al. 2013; Baek et al. 2015; Palla and Gnecco 2015). As an addition to current urban stormwater networks, LIDs can help to manage the potential flooding impacts of uncontrolled urbanization, increased precipitation rates and changing weather patterns linking to climate change. LID techniques help to decrease surface runoff through the preservation, percolation and evapotranspiration of stormwater. LIDs consider more extensive approaches for runoff reduction than conventional frameworks, which introduce them as a more integrated and sustainable approach to urban stormwater management (Field et al., 2005; Wang et al., 2010; Son et al. 2017; Zischg et al. 2017; Zhu and Chen, 2017; Goncalves et al. 2018).

\section{Challenges in climate-change-induced flood mitigation using LID}

Though LIDs have proven to be effective in reducing the severity of urban floods and have been put forward as tools for mitigating increasingly severe flooding events which are likely to result from a changing climate, a number of challenges remain in regards their increased use. Several studies have identified the barriers to more widespread implementation. Roy et al. (2008) reported seven common barriers. These include uncertainties in the cost and performance, absence of standards and implementation procedures, disintegrated obligations, insufficient institutional capability, shortcomings of the governmental directive, financial limitations, and environmental conflict.

Barriers identified in other studies include those related to personal attitude, prevailing socioinstitutional conditions (including strategies and governance), and social and organizational cultures (Brown and Farrelly 2009a, b; Matthews et al. 2015; O'Donnell et al. 2017; Pappalardo and La Rosa, 2020). 
Knowledge on the maintenance costs and long-term benefits of LIDs is also still very limited. It is generally considered that the implementation cost of LIDs is less and therefore, it potentially is a very cost-effective adaptation tool for flood mitigation. A few studies have, however, reported high maintenance costs due to the requirement to have a skilled and knowledgeable workforce available for ongoing work (Hewitt et al., 2019). The efficiency of an LID also does reduce with time, even with regular maintenance, and they may not prove to be effective in the longer-term due to changes in variables such as rainfall intensity increasing over time resulting from climate change. For example, it is very difficult to sustain the perviousness of porous media even with proper maintenance. The effectiveness of retention ponds also reduces with time, and these are often very costly to maintain. The installation of these particular structures is often cost-effective, however the maintenance costs are substantial, often making the LID overall more costly than the traditional pipe-to-sewer stormwater infrastructure. Further technological improvements in LID structures to increase longevity and reduce maintenance costs are needed. One big challenge is that most areas of the world lack the technical and human capability to implement LID practices. A standard procedure should be developed to identify the best LID practices and the procedures for implementing and maintaining them in a cost-effective manner.

One of the biggest operational challenges in many countries is determining the location of a suitable place for an LID in a densely-populated and highly-developed urban area. Mitigation of floods is particularly important for these densely populated cities, where the impact of any flooding is much greater (Shahid et al. 2016; La Rosa and Pappalardo, 2020). Usually the urban drainage systems found in cities in developing countries have been constructed in a haphazard and usually unsustainable manner and finding suitable locations for an LID installation, as a supplement to existing drainage structures, is a major challenge (Shafique and Kim, 2017). The use of highly sophisticated LIDs, such as porous asphalt pavement, have been suggested (Hu et al., 2018), however these are not cost-effective for many poorer countries. Research directed at reducing the implementation costs of LIDs in such regions should be given priority.

Lack of knowledge on best LID practices and the optimum design specification of LIDs are other major challenges. No universal design standard for LIDs is available, and construction and operation is usually based on the specifications developed and used in developed countries. As the development and operation of an LID can be very sensitive to local climatic and geographic factors, this may cause problems in successful implementation and operation.in different climatic zones. Parker and Zingoni de Baro (2019) found most of 
the studies were conducted in cooler climate regions, particularly in the colder regions, while very limited studies were carried out in the continents of Asia, Africa and South America. Studies in warmer climatic regions, therefore, are very limited though they actually tend to be the most vulnerable to climate-change-induced urban floods. For this reason further studies are important, and needed to identify optimum LID specifications and develop suitable guidelines for LID implementation in regions with varying climatic and geographical characteristics.

All LIDs do not perform equally well even in the same environment. Therefore recognition of the site-specific performance of a particular LID is important when choosing the appropriate installation for an area. Vegetated filter strips, for example, may be suitable for a small parking space but not for a large drainage zone. Porous pavement is found to be very effective for flood mitigation in most of the studies conducted, however it may not be cost-effective in all regions of the world. Further research to provide information on the best LID practices, and the best and most effective combination of LIDs, is therefore very important.

Few studies have examined the limitations of LIDs in flood mitigation even when they are installed using optimum specifications and guidelines. Wilbanks and Fernandez (2014) noted that LIDs can control only the initial few inches of a storm event and are thus unable to prevent large-scale local flooding. Sohn et al. (2019) prepared a systematic review to identify climate impacts on LIDs, but only provided information on effectiveness under reduced-intensity, short-period storms. Hua et al. (2019) also noted that runoff control by LIDs is only effective in the case of mild storms. Even with the limitations in capability or adaptability of conventional structures for flood mitigation in the context of climate change, the retrofitting of these existing, conventional structures or implementation of new structures such as flood control works, high standard embankments and flood tunnels should be given a very high priority. Research findings also suggest that LIDs can only supplement existing SWMS. Finding the optimal combination of conventional SWMS and contemporary LIDs is a challenge which requires a solution (Qiao et al., 2020).

The social acceptability of LID practices is another issue to overcome in regards successful LID implementation. In developing countries there tends to be little acceptance of such technologies, even in regions where urban floods are a frequent occurrence. There also tends to be a lack of government interest and associated policy focus. Most of the municipalities in developing countries do not consider LID implementation as a high priority, mostly due to a lack of knowledge about technological alternatives. Overcoming these 
obstacles requires an increased awareness of the issues on the part of society as a whole, which can lead to increased attention by government and more focused policy directives (Dhakal and Chevalier, 2017).

Some other potential limiting factors includes the requirement for approval from local authorities, rising maintenance costs and decreasing ability to reduce pollutants as the structures age, elevated levels of erosion during intense storm events, the high risk of pavement failure around LID interfaces, increased obligations and safety concerns, and an overall reduction in performance over time.

Barriers to LID implementation were found to differ between the developing and developed countries. Socio-political barriers are the most important in developed countries while capacity and technical barriers tend to be the most important barriers in developing countries. Dhakal and Chevalier (2017) showed that the most serious obstacles to successful LID implementation in North American cities are perceptual limitations and socioinstitutional resistance. Other obstacles include resource and policy limitations, which are also the result of the first two factors. Social approval is possibly the most critical factor in regards the technology aspect, and the most effective enabler in regards barrier removal. Matthews et al. (2015) suggested that socio-political drivers may be the reason for the existence of barriers in the implementation of LIDs in the UK. Zhao et al., (2019) mentioned the absence of a governing institution and associated regulations, a lack of rigorous development standards, a lack of incentives and reduced market values, as barriers to the success of LID practices in Brazil. Gashu and Gebre-Egziabher 2019 showed capacity and technical barriers were the leading barriers in LID implementations in a developing country such as Ethiopia. Knowledge about LID technology is still very limited, and mainly resides with the main stakeholders and the government agencies responsible for flood mitigation. Acceptance of these technologies is still very low in developing countries where urban floods are common due to generally unsustainable urban growth. A growing awareness of the use of LIDs is required in order to successfully implement LID practices.

\section{Conclusions}

This article has presented information on the role climate change plays in urban flooding events, and has assessed the strengths and limitations of implementing LID practices for controlling urban floods resulting from a changing climate. The intensity of observed changes in urban areas may arise due to a combination of local urban climate variability and globalwarming-induced climate change. These factors can result in a higher frequency as well as 
severity of rainfall extremes, and consequent flooding of urban areas. It is evident that the use of LIDs can be a cost-effective option. LIDs can be used to supplement a conventional urban stormwater management system and assist in handling the large uncertainties in flood peaks, as well as mitigating possible flooding risk, in a cost-effective manner. Certain types of LIDs tend to be more easily implemented, and more effective in reducing urban floods, at differing rainfall intensity levels. The permeable pavement appears to be most effective in reducing the peak flow from shorter duration rainfall events, while bioretention cells or storage layers are more effective in dealing with floods caused by long duration, intense rainfall. In general, it appears that the effectiveness of a certain type of LID, within a specific region, depends on the selection of optimum LID parameters, taking into consideration rainfall patterns and a combination of different LIDs operating in an integrated manner. The optimum design specification of LIDs, and best combinations of LIDs based on the projected rainfall patterns, are important factors to consider when using LIDs as tools to combat increasing levels of urban flooding. Acceptance and use of such technologies is still very low in developing countries, notably in areas where urban flood events tend to be more frequent and widespread. The study revealed some of the major challenges facing the successful implementation of LIDs for urban flood mitigation. This included a lack of knowledge of best LID practices, difficulty in obtaining optimum design specifications, the lack of suitable space required for successfully implementing these practices in densely-populated and highly-developed urban areas, the ability to integrate LID practices with existing, complex, urban infrastructure, a lack of social acceptability in regards the technology, a lack of standard procedures for the installation and maintenance of these structures in developing countries, a requirement of frequent maintenance and a general reduction in the efficiency of the LID over time. Research aimed at improving the technology supporting LIDs, as well as improving the structure longevity and reducing maintenance costs, is important if these methods are to gain wider acceptance. A growing awareness of LID practices and acceptance of the technology by stakeholders is also essential. It is expected that this study will help promote LID practices, practices which have the potential to assist in mitigating urban flooding. This will in turn assist in achieving the millennium goal of developing sustainable cities.

\section{Declaration of interests}

The authors declare that they have no known competing financial interests or personal relationships that could have appeared to influence the work reported in this paper. 


\section{Acknowledgments}

The authors are grateful to the Universiti Teknologi Malaysia for providing financial support for this research through a Post-Doctoral Fellowship Scheme of the Universiti Teknologi Malaysia, Grant Number Q.J130000.21A2.04E38.

\section{References}

Ahiablame, L., Chaubey, I., Engel, B., Cherkauer, K., Merwade, V., 2013. Estimation of annual baseflow at ungauged sites in Indiana USA. J. Hydrol. 476, 13-27. https://doi.org/10.1016/j.jhydrol.2012.10.002

Ahiablame, L., Shakya, R., 2016. Modeling flood reduction effects of low impact development at a watershed scale. J. Environ. Manage. 171, 81-91. https://doi.org/10.1016/j.jenvman.2016.01.036

Ahmed, K., Chung, E.-S., Song, J.-Y., Shahid, S., 2017. Effective Design and Planning Specification of Low Impact Development Practices Using Water Management Analysis Module (WMAM): Case of Malaysia. Water 9, 173. https://doi.org/10.3390/w9030173

Akter, T., Quevauviller, P., Eisenreich, S.J., Vaes, G., 2018. Impacts of climate and land use changes on flood risk management for the Schijn River, Belgium. Environ. Sci. Policy 89, 163-175. https://doi.org/10.1016/j.envsci.2018.07.002

Alfieri, L., Feyen, L., Dottori, F., Bianchi, A., 2015. Ensemble flood risk assessment in Europe under high end climate scenarios. Glob. Environ. Chang. 35, 199-212. https://doi.org/10.1016/j.gloenvcha.2015.09.004

Alfredo, K., Montalto, F., Goldstein, A., 2010. Observed and modeled performances of prototype green roof test plots subjected to simulated low-and high-intensity precipitations in a laboratory experiment. J. Hydrol. Eng. 15, 444-457. https://doi.org/10.1061/(ASCE)HE.1943-5584.0000135

Ali, H., Mishra, V., Pai, D.S., 2014. Observed and projected urban extreme rainfall events in India. J. Geophys. Res. Atmos. 119, 12-621. https://doi.org/10.1002/2014JD022264

Anandhi, A., Omani, N., Chaubey, I., Horton, R., Bader, D.A., Nanjundiah, R.S., 2016. Synthetic scenarios from CMIP5 model simulations for climate change impact assessments in managed ecosystems and water resources: Case study in South Asian Countries. Trans. ASABE 59, 1715-1731. https://doi.org/10.13031/trans.59.11585

Angel, S., Parent, J., Civco, D.L., Blei, A., Potere, D., 2011. The dimensions of global urban expansion: Estimates and projections for all countries, 2000-2050. Prog. Plann. 75, 53- 
107. https://doi.org/10.1016/j.progress.2011.04.001

Anker, Y., Mirlas, V., Gimburg, A., Zilberbrand, M., Nakonechny, F., Meir, I., Inbar, M., 2019. Effect of rapid urbanization on Mediterranean karstic mountainous drainage basins. Sustain. Cities Soc. 51, 101704. https://doi.org/10.1016/j.scs.2019.101704

Bacchin, T.K., Ashley, R., Sijmons, D., Zevenbergen, C., Van Timmeren, A., 2014. Greenblue multifunctional infrastructure: An urban landscape system design new approach, in: 13th International Conference on Urban Drainage, Sarawak, Malaysia. pp. 7-12.

Baek, S., Choi, D., Jung, J., Lee, Hyung-jin, Lee, Hyuk, Yoon, K., Hwa, K., 2015. Optimizing low impact development ( LID ) for stormwater runoff treatment in urban area , Korea: Experimental and modeling approach. Elsevier 86, 122-131. https://doi.org/10.1016/j.watres.2015.08.038

Bahrami, M., Bozorg-Haddad, O., Loáiciga, H.A., 2019. Optimizing stormwater low-impact development strategies in an urban watershed considering sensitivity and uncertainty. Environ. Monit. Assess. 191, 340. https://doi.org/10.1007/s10661-019-7488-y

Bajracharya, A.R., Bajracharya, S.R., Shrestha, A.B., Maharjan, S.B., 2018. Climate change impact assessment on the hydrological regime of the Kaligandaki Basin, Nepal. Sci. Total Environ. 625, 837-848. https://doi.org/10.1016/j.scitotenv.2017.12.332

Barbosa, A.E., Fernandes, J.N., David, L.M., 2012. Key issues for sustainable urban stormwater management. Water Res. 46, 6787-6798. https://doi.org/10.1016/j.watres.2012.05.029

Brown, R. R., Farrelly, M.A., 2009a. Challenges ahead: social and institutional factors influencing sustainable urban stormwater management in Australia. Water Sci. Technol. 59, 653-660. https://doi.org/10.2166/wst.2009.022

Brown, R. R., Farrelly, M.A., 2009b. Delivering sustainable urban water management: a review of the hurdles we face. Water Sci. Technol. 59, 839-846. https://doi.org/10.2166/wst.2009.028

Brunetti, G., Šimůnek, J., Turco, M., Piro, P., 2017. On the use of surrogate-based modeling for the numerical analysis of Low Impact Development techniques. J. Hydrol. 548, 263277. https://doi.org/10.1016/j.jhydrol.2017.03.013

Byun, K., Hamlet, A.F., 2018. Projected changes in future climate over the Midwest and Great Lakes region using downscaled CMIP5 ensembles. Int. J. Climatol. 38, e531e553. https://doi.org/10.1002/joc.5388

Cabrera, J., Lee, H., 2018. Impacts of climate change on flood-prone areas in Davao oriental, Philippines. Water 10, 893. https://doi.org/10.3390/w10070893 
Chang, N.-B., 2010. Hydrological Connections between Low-Impact Development, Watershed Best Management Practices, and Sustainable Development. J. Hydrol. Eng. 15, 384-385. https://doi.org/10.1061/(ASCE)HE.1943-5584.0000236

Chang, N., Lu, J., Chui, T., Policy, N.H., 2018. Global policy analysis of low impact development for stormwater management in urban regions. Land use policy 70, 368383. https://doi.org/10.1016/j.landusepol.2017.11.024

Changnon, S.A., 1979. What to do About Urban-generated Weather and Climate Changes. J. Am. Plan. Assoc. 45, 36-47. https://doi.org/10.1080/01944367908976937

Chaosakul, T.A., Koottatep, T., Irvine, K., 2013. Low impact development modeling to assess localized flood reduction in Thailand. J. Water Manag. Model. 6062, 337-354. https://doi.org/DOI: 10.14796/JWMM.R246-18

Chen, B., Liu, J., She, N., Xu, K., 2015. Optimization of Low-Impact Development Facilities in the Beijing CITIC Complex, in: International Low Impact Development Conference 2015: LID: It Works in All Climates and Soils. pp. 342-351. https://doi.org/10.1061/9780784479025.035

Chen, Y., Tan, M., Wan, J., Weise, T., Wu, Z., 2020. Effectiveness evaluation of the coupled LIDs from the watershed scale based on remote sensing image processing and SWMM simulation. Eur. J. Remote Sens. 1-15. https://doi.org/10.1080/22797254.2020.1758962

Chui, T.F.M., Liu, X., Zhan, W., 2016. Assessing cost-effectiveness of specific LID practice designs in response to large storm events. J. Hydrol. 533, 353-364. https://doi.org/10.1016/j.jhydrol.2015.12.011

Cooper, R.T., 2019. Projection of future precipitation extremes across the Bangkok Metropolitan Region. Heliyon 5, e01678. https://doi.org/10.1016/j.heliyon.2019.e01678

Czemiel Berndtsson, J., 2010. Green roof performance towards management of runoff water quantity and quality: A review. Ecol. Eng. 36, 351-360. https://doi.org/10.1016/j.ecoleng.2009.12.014

DeGaetano, A.T., Castellano, C.M., 2017. Future projections of extreme precipitation intensity-duration-frequency curves for climate adaptation planning in New York State. Clim. Serv. 5, 23-35. https://doi.org/10.1016/j.cliser.2017.03.003

Dewan, A.M., Corner, R.J., 2014. Impact of land use and land cover changes on urban land surface temperature, in: Dhaka Megacity. Springer, Dordrecht, pp. 219-238. https://doi.org/10.1007/978-94-007-6735-5_12

Dhakal, K.P., Chevalier, L.R., 2017. Managing urban stormwater for urban sustainability: Barriers and policy solutions for green infrastructure application. J. Environ. Manage. 
203, 171-181. https://doi.org/10.1016/j.jenvman.2017.07.065

Dietz, M.E., 2007. Low impact development practices: A review of current research and recommendations for future directions. Water. Air. Soil Pollut. 186, 351-363.

Dixon, P.G., Mote, T.L., 2003. Patterns and causes of Atlanta's urban heat island-initiated precipitation. J. Appl. Meteorol. 42, 1273-1284. https://doi.org/10.1175/15200450(2003)042<1273:PACOAU>2.0.CO;2

Doherty, J., 2010. PEST, Model-Independent Parameter Estimation-User Manual. 5th Edition, with Slight Additions, Watermark Numerical Computing,Brisbane.

Dong, G., Weng, B., Qin, T., Yan, D., Wang, H., Gong, B., Bi, W., Xing, Z., 2018. The Impact of the Construction of Sponge Cities on the Surface Runoff in Watersheds, China. Adv. Meteorol. Article ID 6241892. https://doi.org/10.1155/2018/6241892

Dong, X., Guo, H., Zeng, S., 2017. Enhancing future resilience in urban drainage system: Green versus grey infrastructure. Water Res. 124, 280-289. https://doi.org/10.1016/j.watres.2017.07.038

Dreelin, E.A., Fowler, L., Ronald Carroll, C., 2006. A test of porous pavement effectiveness on clay soils during natural storm events. Water Res. 40, 799-805. https://doi.org/10.1016/j.watres.2005.12.002

Du, S., Shi, P., Van Rompaey, A., Wen, J., 2015. Quantifying the impact of impervious surface location on flood peak discharge in urban areas. Nat. Hazards 76, 1457-1471. https://doi.org/10.1007/s11069-014-1463-2

Du, S., Wang, C., Shen, J., Wen, J., Gao, J., Wu, J., Lin, W., Xu, H., 2019. Mapping the capacity of concave green land in mitigating urban pluvial floods and its beneficiaries. Sustain. Cities Soc. 44, 774-782. https://doi.org/10.1016/j.scs.2018.11.003

Duan, H.-F., Li, F., Yan, H., 2016. Multi-Objective Optimal Design of Detention Tanks in the Urban Stormwater Drainage System: LID Implementation and Analysis. Water Resour. Manag. 30, 4635-4648. https://doi.org/10.1007/s11269-016-1444-1

Eckart, K., McPhee, Z., Bolisetti, T., 2018. Multiobjective optimization of low impact development stormwater controls. J. Hydrol. 562, 564-576. https://doi.org/10.1016/j.jhydrol.2018.04.068

Eckart, K., McPhee, Z., Bolisetti, T., 2017. Performance and implementation of low impact development - A review. Sci. Total Environ. 607-608, 413-432. https://doi.org/10.1016/j.scitotenv.2017.06.254

Elliott, A.H., Trowsdale, S.A., 2007. A review of models for low impact urban stormwater drainage. Environ.

Model.

Softw.

22 ,

394-405. 
https://doi.org/10.1016/j.envsoft.2005.12.005

EM-DAT, 2019. Economic Losses, Poverty and Disasters 1998-2017. http://www.emdat.be, Accessed 9th Jan 2019

ESRI, R., 2011. ArcGIS desktop: release 10. Environ. Syst. Res. Institute, CA.

Field, J.P., Farrish, K.W., Oswald, B.P., Romig, M.T., Carter, E.A., 2005. Forest site preparation effects on soil and nutrient losses in east Texas. Trans. ASAE 48, 861-869. https://doi.org/10.13031/2013.18294

Flanagan, K., Branchu, P., Boudahmane, L., Caupos, E., Demare, D., Deshayes, S., Dubois, P., Meffray, L., Partibane, C., Saad, M., Gromaire, M.-C., 2018. Field performance of two biofiltration systems treating micropollutants from road runoff. Water Res. 145, 562-578. https://doi.org/10.1016/j.watres.2018.08.064

Fletcher, T.D., Vietz, G., Walsh, C.J., 2014. Protection of stream ecosystems from urban stormwater runoff: The multiple benefits of an ecohydrological approach. Prog. Phys. Geogr. 38, 543-555. https://doi.org/10.1177/0309133314537671

Freitag, B.M., Nair, U.S., Niyogi, D., 2018. Urban modification of convection and rainfall in complex terrain. Geophys. Res. Lett. 45, 2507-2515. https://doi.org/10.1002/2017GL076834

Gashu, K., Gebre-Egziabher, T., 2019. Barriers to green infrastructure development and planning in two Ethiopian cities: Bahir Dar and Hawassa. Urban Ecosyst. 22, 657-669. https://doi.org/10.1007/s11252-019-00852-y

Ghisi, E., Cardoso, K.A., Rupp, R.F., 2012. Short-term versus long-term rainfall time series in the assessment of potable water savings by using rainwater in houses. J. Environ. Manage. 100, 109-119. https://doi.org/10.1016/j.jenvman.2011.12.031

Ghodsi, S.H., Zahmatkesh, Z., Goharian, E., Kerachian, R., Zhu, Z., 2020. Optimal design of low impact development practices in response to climate change. J. Hydrol. 580, 124266. https://doi.org/10.1016/j.jhydrol.2019.124266

Gilroy, K.L., McCuen, R.H., 2009. Spatio-temporal effects of low impact development practices. J. Hydrol. 367, 228-236. https://doi.org/10.1016/j.jhydrol.2009.01.008

Goncalves, L.R.M., Zischg, J., Rau, S., Sitzmann, M., Rauch, W., Kleidorfer, M., 2018. Modeling the Effects of Introducing Low Impact Development in a Tropical City: A Case Study from Joinville, Brazil. Sustain. . https://doi.org/10.3390/su10030728

Guerreiro, S.B., Dawson, R.J., Kilsby, C., Lewis, E., Ford, A., 2018. Future heat-waves, droughts and floods in 571 European cities. Environ. Res. Lett. 13, 34009. https://doi.org//10.1088/1748-9326/aaaad3 
Guo, J., Huang, G., Wang, X., Li, Y., Yang, L., 2018. Future changes in precipitation extremes over China projected by a regional climate model ensemble. Atmos. Environ. 188, 142-156. https://doi.org/10.1016/j.atmosenv.2018.06.026

Guoshun, Z., Patrick, R., Yong, T., 2013. Multi-objective optimization of low impact development designs in an urbanizing watershed. Open J. Optim. 2, 95-108. https://doi.org/10.4236/ojop.2013.24013

Hamel, P., Daly, E., Fletcher, T.D., 2013. Source-control stormwater management for mitigating the impacts of urbanisation on baseflow: A review. J. Hydrol. 485, 201-211. https://doi.org/10.1016/j.jhydrol.2013.01.001

He, C., Liu, Z., Gou, S., Zhang, Q., Zhang, J., Xu, L., 2019. Detecting global urban expansion over the last three decades using a fully convolutional network. Environ. Res. Lett. 14, 34008. https://doi.org/10.1088/1748-9326/aaf936

Hettiarachchi, S., Wasko, C., Sharma, A., 2018. Increase in flood risk resulting from climate change in a developed urban watershed - the role of storm temporal patterns. Hydrol. Earth Syst. Sci. 22, 2041-2056. https://doi.org/10.5194/hess-22-2041-2018

Hewitt, E., Oberg, A., Coronado, C., Andrews, C., 2019. Assessing "green" and "resilient" building features using a purposeful systems approach. Sustain. Cities Soc. 48, 101546. https://doi.org/10.1016/j.scs.2019.101546

Hirsch, R.M., Ryberg, K.R., 2012. Has the magnitude of floods across the USA changed with global $\mathrm{CO} 2$ levels? Hydrol. Sci. J. https://doi.org/10.1080/02626667.2011.621895

Hu, M., Sayama, T., Zhang, X., Tanaka, K., Takara, K., Yang, H., 2017. Evaluation of low impact development approach for mitigating flood inundation at a watershed scale in China. J. Environ. Manage. 193, 430-438. https://doi.org/10.1016/j.jenvman.2017.02.020

Hu, M., Zhang, X., Siu, L.Y., Li, Y., Tanaka, K., Yang, H., Xu, Y., 2018. Flood Mitigation by Permeable Pavements in Chinese Sponge City Construction. Water . https://doi.org/10.3390/w10020172

Hua, P., Yang, W., Qi, X., Jiang, S., Xie, J., Gu, X., Li, H., Zhang, J., Krebs, P., 2019. Evaluating the effect of urban flooding reduction strategies in response to design rainfall and low impact development. J. Clean. Prod. 118515. https://doi.org/10.1016/j.jclepro.2019.118515

Huang, C.-L., Hsu, N.-S., Wei, C.-C., Luo, W.-J., 2015. Optimal spatial design of capacity and quantity of rainwater harvesting systems for urban flood mitigation. Water 7, 5173- 
5202. https://doi.org/10.3390/w7095173

Huang, C.L., Hsu, N.S., Liu, H.J., Huang, Y.H., 2018. Optimization of low impact development layout designs for megacity flood mitigation. J. Hydrol. 564, 542-558. https://doi.org/10.1016/j.jhydrol.2018.07.044

Huang, J., He, J., Valeo, C., Chu, A., 2016. Temporal evolution modeling of hydraulic and water quality performance of permeable pavements. J. Hydrol. 533, 15-27. https://doi.org/10.1016/j.jhydrol.2015.11.042

Hulley, M., Watt, E., Zukovs, G., 2008. Potential impacts of climate change on stormwater management, in: XCG Consultants Ltd. WaterTech2008 Conference, Lake Louise, Alberta.

Jackisch, N., Weiler, M., 2017. The hydrologic outcome of a Low Impact Development (LID) site including superposition with streamflow peaks. Urban Water J. 14, 143-159. https://doi.org/10.1080/1573062X.2015.1080735

Januriyadi, N.F., Kazama, S., Moe, I.R., Kure, S., 2018. Evaluation of future flood risk in Asian megacities: a case study of Jakarta. Hydrol. Res. Lett. 12, 14-22.

Jegatheesan, V., Goonetilleke, A., van Leeuwen, J., Kandasamy, J., Warner, D., Myers, B., Bhuiyan, M., Spence, K., Parker, G., 2019. Urban Stormwater and Flood Management: Enhancing the Liveability of Cities. Springer, Berline. https://doi.org/DOI: 10.1007/9783-030-11818-1

Jia, H., Lu, Y., Yu, S.L., Chen, Y., 2012. Planning of LID-BMPs for urban runoff control: The case of Beijing Olympic Village. Sep. Purif. Technol. 84, 112-119. https://doi.org/10.1016/j.seppur.2011.04.026

Joyce, J., Chang, N.-B., Harji, R., Ruppert, T., 2018. Coupling infrastructure resilience and flood risk assessment via copulas analyses for a coastal green-grey-blue drainage system under extreme weather events. Environ. Model. Softw. 100, 82-103. https://doi.org/10.1016/j.envsoft.2017.11.008

Juan, A., Hughes, C., Fang, Z., Bedient, P., 2017. Hydrologic Performance of WatershedScale Low-Impact Development in a High-Intensity Rainfall Region. J. Irrig. Drain. Eng. 143, 4016083. https://doi.org/10.1061/(ASCE)IR.1943-4774.0001141

Kamali, M., Delkash, M., Tajrishy, M., 2017. Evaluation of permeable pavement responses to urban surface runoff. J. Environ. Manage. 187, 43-53. https://doi.org/10.1016/j.jenvman.2016.11.027

Karamouz, M., Zahmatkesh, Z., 2017. Quantifying resilience and uncertainty in coastal flooding events: framework for assessing urban vulnerability. J. Water Resour. Plan. 
Manag. 143, 4016071. https://doi.org/10.1061/(ASCE)WR.1943-5452.0000724

Khan, N., Shahid, S., Juneng, L., Ahmed, K., Ismail, T., Nawaz, N., 2019. Prediction of heat waves in Pakistan using quantile regression forests. Atmos. Res. 221, 1-11. https://doi.org/10.1016/j.atmosres.2019.01.024

Kong, F., Ban, Y., Yin, H., James, P., Dronova, I., 2017. Modeling stormwater management at the city district level in response to changes in land use and low impact development. Environ. Model. Softw. 95, 132-142. https://doi.org/10.1016/j.envsoft.2017.06.021

La Rosa, D., Pappalardo, V., 2020. Planning for spatial equity - A performance based approach for sustainable urban drainage systems. Sustain. Cities Soc. 53, 101885. https://doi.org/10.1016/j.scs.2019.101885

Landsberg, H.E., 1981. The urban climate. Academic press, New York.

Latif, M., 2013. Uncertainty in climate change projections, in: Hasselmann, K., Jaeger, C., Leipold, G., Mangalagiu, D., \& Tàbara, J. D. (eds) Reframing the Problem of Climate Change. London, Routledge, pp. 31-48. https://doi.org/10.4324/9780203154724

Lee, J., Hyun, K., Choi, J., 2013. Analysis of the impact of low impact development on runoff from a new district in Korea. Water Sci. Technol. 68, 1315-1321. https://doi.org/10.2166/wst.2013.346

Li, F., Yan, X.-F., Duan, H.-F., 2019. Sustainable Design of Urban Stormwater Drainage Systems by Implementing Detention Tank and LID Measures for Flooding Risk Control and Water Quality Management. Water Resour. Manag. 33, 3271-3288. https://doi.org/10.1007/s11269-019-02300-0

Li, J., Deng, C., Li, Y., Li, Y., Song, J., 2017a. Comprehensive Benefit Evaluation System for Low-Impact Development of Urban Stormwater Management Measures. Water Resour. Manag. 31, 4745-4758. https://doi.org/10.1007/s11269-017-1776-5

Li, X., Zhou, Y., Asrar, G.R., Imhoff, M., Li, Xuecao, 2017b. The surface urban heat island response to urban expansion: A panel analysis for the conterminous United States. Sci. Total Environ. 605-606, 426-435. https://doi.org/10.1016/j.scitotenv.2017.06.229

Liang, P., Ding, Y.H., He, J.H., Tang, X., 2013. Study of relationship between urbanization speed and change of spatial distribution of rainfall over Shanghai. J. Trop. Meteorol. 19, 97-103.

Lim, H.S., Lu, X.X., 2016. Sustainable urban stormwater management in the tropics: An evaluation of Singapore's ABC Waters Program. J. Hydrol. 538, 842-862. https://doi.org/10.1016/j.jhydrol.2016.04.063

Liu, J., Niyogi, D., 2019. Meta-analysis of urbanization impact on rainfall modification. Sci. 
Rep. 9, 7301. https://doi.org/10.1038/s41598-019-42494-2

Liu, Y., Bralts, V.F., Engel, B.A., 2015. Evaluating the effectiveness of management practices on hydrology and water quality at watershed scale with a rainfall-runoff model. Sci. Total Environ. 511, 298-308. https://doi.org/10.1016/j.scitotenv.2014.12.077

Mallakpour, I., AghaKouchak, A., Sadegh, M., 2019. Climate-Induced Changes in the Risk of Hydrological Failure of Major Dams in California. Geophys. Res. Lett. 46, 21302139. https://doi.org/10.1029/2018GL081888

Markus, M., Angel, J., Byard, G., McConkey, S., Zhang, C., Cai, X., Notaro, M., Ashfaq, M., 2018. Communicating the impacts of projected climate change on heavy rainfall using a weighted ensemble approach. J. Hydrol. Eng. 23, 4018004. https://doi.org/10.1061/(ASCE)HE.1943-5584.0001614

Matthews, T., Lo, A.Y., Byrne, J.A., 2015. Reconceptualizing green infrastructure for climate change adaptation: Barriers to adoption and drivers for uptake by spatial planners. Landsc. Urban Plan. 138, 155-163. https://doi.org/10.1016/j.landurbplan.2015.02.010

Men, H., Lu, H., Jiang, W., Xu, D., 2020. Mathematical Optimization Method of Low-Impact Development Layout in the Sponge City. Math. Probl. Eng. 2020, 6734081. https://doi.org/10.1155/2020/6734081

Mikkelsen, P.S., 2004. Retrofitting Urban Drainage Systems Using Best Stormwater Management Practices-Some Scandinavian Experiences, in: Marsalek J., Sztruhar D., Giulianelli M., U.B. (Ed.), Enhancing Urban Environment by Environmental Upgrading and Restoration. Nato Science Series: IV: Earth and Environmental Sciences, vol 43. Springer, Dordrecht, pp. 1-12.https://doi.org/10.1007/1-4020-2694-3_1

Miller, J.D., Hutchins, M., 2017. The impacts of urbanisation and climate change on urban flooding and urban water quality: A review of the evidence concerning the United Kingdom. J. Hydrol. Reg. Stud. 12, 345-362. https://doi.org/10.1016/j.ejrh.2017.06.006

Mishra, B.K., Rafiei Emam, A., Masago, Y., Kumar, P., Regmi, R.K., Fukushi, K., 2018. Assessment of future flood inundations under climate and land use change scenarios in the Ciliwung River Basin, Jakarta. J. Flood Risk Manag. 11, S1105-S1115. https://doi.org/10.1111/jfr3.12311

Mohtar, W.H.M.W., Abdullah, J., Abdul Maulud, K.N., Muhammad, N.S., 2020. Urban flash flood index based on historical rainfall events. Sustain. Cities Soc. 56, 102088. https://doi.org/10.1016/j.scs.2020.102088

Morsy, M.M., Goodall, J.L., Shatnawi, F.M., Meadows, M.E., 2016. Distributed stormwater controls for flood mitigation within urbanized watersheds: Case study of Rocky Branch 
Watershed in Columbia, South Carolina. J. Hydrol. Eng. 21, 5016025. https://doi.org/10.1061/(ASCE)HE.1943-5584.0001430

Mukherjee, S., Aadhar, S., Stone, D., Mishra, V., 2018. Increase in extreme precipitation events under anthropogenic warming in India. Weather Clim. Extrem. 20, 45-53. https://doi.org/10.1016/j.wace.2018.03.005

Müller, N., Ignatieva, M., Nilon, C.H., Werner, P., Zipperer, W.C., 2013. Patterns and trends in urban biodiversity and landscape design, in: Elmqvist, T. et al. (eds) Urbanization, Biodiversity and Ecosystem Services: Challenges and Opportunities: a global assessment. Springer, Dordrecht, pp. 123-174. https://doi.org/10.1007/978-94-0077088-1

Nashwan, M.S., Ismail, T., Ahmed, K., 2019. Non-stationary analysis of extreme rainfall in peninsular Malaysia. J. Sustain. Sci. Manag. 14, 17-34.

Nguyen, H.Q., Radhakrishnan, M., Bui, T.K.N., Tran, D.D., Ho, L.P., Tong, V.T., Huynh, L.T.P., Chau, N.X.Q., Ngo, T.T.T., Pathirana, A., Ho, H.L., 2019. Evaluation of retrofitting responses to urban flood risk in Ho Chi Minh City using the Motivation and Ability (MOTA) framework. Sustain. Cities Soc. 47, 101465. https://doi.org/10.1016/j.scs.2019.101465

Noor, M., Ismail, T., Chung, E.-S., Shahid, S., Sung, J., 2018. Uncertainty in rainfall intensity duration frequency curves of peninsular Malaysia under changing climate scenarios. Water 10, 1750. https://doi.org/10.3390/w10121750

O’Donnell, E.C., Lamond, J.E., Thorne, C.R., 2017. Recognising barriers to implementation of Blue-Green Infrastructure: a Newcastle case study. Urban Water J. 14, 964-971. https://doi.org/10.1080/1573062X.2017.1279190

Oberascher, M., Zischg, J., Palermo, S.A., Kinzel, C., Rauch, W., Sitzenfrei, R., 2019. Smart Rain Barrels: Advanced LID Management Through Measurement and Control, in: Mannina G. (eds) New Trends in Urban Drainage Modelling, UDM 2018. Green Energy and Technology. Springer, Cham, pp. 777-782. https://doi.org/10.1007/978-3-31999867-1_134

Palanisamy, B., Chui, T.F.M., 2015. Rehabilitation of concrete canals in urban catchments using low impact development techniques. J. Hydrol. 523, 309-319. https://doi.org/10.1016/j.jhydrol.2015.01.034

Palermo, S.A., Talarico, V.C., Pirouz, B., 2020a. Optimizing rainwater harvesting systems for non-potable water uses and surface runoff mitigation, in: Sergeyev Y., Kvasov D. (eds) Numerical Computations: Theory and Algorithms. NUMTA 2019. Lecture Notes 
in Computer Science, vol 11973. Springer, Cham, pp. 570-582. https://doi.org/10.1007/978-3-030-39081-5_49

Palermo, S.A., Talarico, V.C., Turco, M., 2020b. On the LID systems effectiveness for urban stormwater management: case study in Southern Italy, in: IOP Conference Series: Earth and Environmental Science. IOP Publishing, 410, p. 12012. https://doi.org/10.1088/1755-1315/410/1/012012

Palla, A., Gnecco, I., 2015. Hydrologic modeling of Low Impact Development systems at the urban catchment scale. J. Hydrol. 528, 361-368. https://doi.org/10.1016/j.jhydrol.2015.06.050

Palla, A., Lanza, L.G., La Barbera, P., 2008. A green roof experimental site in the Mediterranean climate, in: Proceedings of the 11th International Conference on Urban Drainage. Edinburgh, Scotland, UK. pp. 1-10.

Pan, Q., 2011. Economic losses from a hypothetical hurricane event in the HoustonGalveston area. Nat. Hazards Rev. 12, 146-155. https://doi.org/10.1061/(ASCE)NH.1527-6996.0000036

Pappalardo, V., La Rosa, D., 2020. Policies for sustainable drainage systems in urban contexts within performance-based planning approaches. Sustain. Cities Soc. 52, 101830. https://doi.org/10.1016/j.scs.2019.101830

Parker, J., Zingoni de Baro, M.E., 2019. Green Infrastructure in the Urban Environment: A $\begin{array}{lllll}\text { Systematic } & \text { Quantitative } & \text { Review. } & \text { Sustainability } & 11, \quad 3182 .\end{array}$ https://doi.org/10.3390/su11113182

Paul, S., Ghosh, S., Mathew, M., Devanand, A., Karmakar, S., Niyogi, D., 2018. Increased spatial variability and intensification of extreme monsoon rainfall due to urbanization. Sci. Rep. 8, 3918. https://doi.org/10.1038/s41598-018-22322-9

Perryman, N., Dixon, P.G., 2013. A radar analysis of urban snowfall modification in Minneapolis-St. Paul. J. Appl. Meteorol. Climatol. 52, 1632-1644. https://doi.org/10.1175/JAMC-D-12-090.1

Poelmans, L., Rompaey, A. Van, Ntegeka, V., Willems, P., 2011. The relative impact of climate change and urban expansion on peak flows: a case study in central Belgium. Hydrol. Process. 25, 2846-2858. https://doi.org/10.1002/hyp.8047

Qiao, X.-J., Liao, K.-H., Randrup, T.B., 2020. Sustainable stormwater management: A qualitative case study of the Sponge Cities initiative in China. Sustain. Cities Soc. 53, 101963. https://doi.org/10.1016/j.scs.2019.101963

Qin, H., Li, Z., Fu, G., 2013. The effects of low impact development on urban flooding under 
different rainfall characteristics. J. Environ. Manage. 129, 577-585. https://doi.org/10.1016/j.jenvman.2013.08.026

Ramyar, R., Zarghami, E., Bryant, M., 2019. Spatio-temporal planning of urban neighborhoods in the context of global climate change: Lessons for urban form design in Tehran, Iran. Sustain. Cities Soc. 51, 101554. https://doi.org/10.1016/j.scs.2019.101554

Randhir, T.O., Raposa, S., 2014. Urbanization and watershed sustainability: Collaborative simulation modeling of future development states. J. Hydrol. 519, 1526-1536. https://doi.org/10.1016/j.jhydrol.2014.08.051

Recanatesi, F., Petroselli, A., Ripa, M.N., Leone, A., 2017. Assessment of stormwater runoff management practices and BMPs under soil sealing: a study case in a peri-urban watershed of the metropolitan area of Rome (Italy). J. Environ. Manage. 201, 6-18. https://doi.org/10.1016/j.jenvman.2017.06.024

Ren, G.-Y., 2015. Urbanization as a major driver of urban climate change. Adv. Clim. Chang. Res. 6, 1-6. https://doi.org/10.1016/j.accre.2015.08.003

Rossman, L.A., 2010. Modeling low impact development alternatives with SWMM. J. Water Manag. Model. 6062, 167-182. https://doi.org/10.14796/JWMM.R236-11

Rossman, L.A., Huber, W.C., 2015. Storm Water Management Model Reference Manual Volume I-Hydrology. US EPA Office of Research and Development, Washington, DC, US Environmental Protection Agency, EPA/600/R-15/162A, 2015.

Roy, A.H., Wenger, S.J., Fletcher, T.D., Walsh, C.J., Ladson, A.R., Shuster, W.D., Thurston, H.W., Brown, R.R., 2008. Impediments and Solutions to Sustainable, Watershed-Scale Urban Stormwater Management: Lessons from Australia and the United States. Environ. Manage. 42, 344-359. https://doi.org/10.1007/s00267-008-9119-1

Sage, J., Berthier, E., Gromaire, M.-C., 2015. Stormwater Management Criteria for On-Site Pollution Control: A Comparative Assessment of International Practices. Environ. Manage. 56, 66-80. https://doi.org/10.1007/s00267-015-0485-1

Salimi, M., Al-Ghamdi, S.G., 2020. Climate change impacts on critical urban infrastructure and urban resiliency strategies for the Middle East. Sustain. Cities Soc. 54, 101948. https://doi.org/10.1016/j.scs.2019.101948

Salman, S.A., Shahid, S., Ismail, T., Rahman, N. bin A., Wang, X., Chung, E.S., 2018. Unidirectional trends in daily rainfall extremes of Iraq. Theor. Appl. Climatol. 134, 1165-1177. https://doi.org/10.1007/s00704-017-2336-x

Sayers, P., Yuanyuan, L., Galloway, G., Penning-Rowsell, E., Fuxin, S., Kang, W., Yiwei, C., Le Quesne, T., 2013. Flood risk management: A strategic approach. Asian 
Development Bank, GIWP, UNESCO and WWF-UK. http://hdl.handle.net/11540/81

Schmitter, P., Goedbloed, A., Galelli, S., Babovic, V., 2016. Effect of catchment-scale green roof deployment on stormwater generation and reuse in a tropical city. J. Water Resour. Plan. Manag. 142, 5016002. https://doi.org/10.1061/(ASCE)WR.1943-5452.0000643

Scholz, M., Grabowiecki, P., 2007. Review of permeable pavement systems. Build. Environ. 42, 3830-3836. https://doi.org/10.1016/j.buildenv.2006.11.016

Schwartz, D., Sample, D.J., Grizzard, T.J., 2017. Evaluating the performance of a retrofitted stormwater wet pond for treatment of urban runoff. Environ. Monit. Assess. 189, 256. https://doi.org/10.1007/s10661-017-5930-6

Sene, K., 2013. Flood Warning, in: Flash Floods. Springer, Berline, pp. 169-198. https://doi.org/10.1007/978-94-007-5164-4_6

Seo, M., Jaber, F., Srinivasan, R., 2017. Evaluating various low-impact development scenarios for optimal design criteria development. Water 9, 270. https://doi.org/10.3390/w9040270

Serre, D., Heinzlef, C., 2018. Assessing and mapping urban resilience to floods with respect to cascading effects through critical infrastructure networks. Int. J. Disaster Risk Reduct. 30, 235-243. https://doi.org/10.1016/j.ijdrr.2018.02.018

Shafique, M., Kim, R., 2017. Green stormwater infrastructure with low impact development concept: A review of current research. Desalin. Water Treat 83, 16-29. https://doi.org/10.5004/dwt.2017.20981

Shahid, S., Wang, X.J., Harun, S. Bin, Shamsudin, S.B., Ismail, T., Minhans, A., 2016. Climate variability and changes in the major cities of Bangladesh: observations, possible impacts and adaptation. Reg. Environ. Chang. 16, 459-471. https://doi.org/10.1007/s10113-015-0757-6

Shannak, S.A., Jaber, F.H., Lesikar, B.J., 2014. Modeling the Effect of Cistern Size, Soil Type, and Irrigation Scheduling on Rainwater Harvesting as a Stormwater Control Measure. Water Resour. Manag. 28, 4219-4235. https://doi.org/10.1007/s11269-0140740-x

Shepherd, J.M., Andersen, T., Strother, C., Horst, A., Bounoua, L., Mitra, C., 2013. Urban climate archipelagos: A new framework for urban impacts on climate. Earthzine.

Silva, M.M., Costa, J., 2016. Costa, J. Flood Adaptation Measures Applicable in the Design of Urban Public Spaces: Proposal for a Conceptual Framework. Water 8, 284. https://doi.org/10.3390/w8070284

Şimşek, Ç.K., Ödül, H., 2019. A method proposal for monitoring the microclimatic change in 
an urban area. Sustain. Cities Soc. 46, 101407. https://doi.org/10.1016/j.scs.2018.12.035

Sohn, W., Kim, J.-H., Li, M.-H., 2017. Low-impact development for impervious surface connectivity mitigation: assessment of directly connected impervious areas (DCIAs). J. Environ. Plan. Manag. 60, 1871-1889. https://doi.org/10.1080/09640568.2016.1264929

Sohn, W., Kim, J.-H., Li, M.-H., Brown, R., 2019. The influence of climate on the effectiveness of low impact development: A systematic review. J. Environ. Manage. 236, 365-379. https://doi.org/10.1016/j.jenvman.2018.11.041

Son, C., Hyun, K., Kim, D., Baek, J., Ban, Y., 2017. Development and Application of a Low Impact Development (LID)-Based District Unit Planning Model. Sustainability 9, 145. https://doi.org/10.3390/su9010145

Song, X., Zhang, J., AghaKouchak, A., Roy, S. Sen, Xuan, Y., Wang, G., He, R., Wang, X., Liu, C., 2014. Rapid urbanization and changes in spatiotemporal characteristics of precipitation in Beijing metropolitan area. J. Geophys. Res. Atmos. 119, 11-250. https://doi.org/10.1002/2014JD022084

Sun, J., Shu, W., 2007. The effect of urban heat island on winter and summer precipitation in Beijing region. Chinese J. Atmos. Sci. Ed. 31, 311-320. https://doi.org/10.3878/j.issn.1006-9895.2007.02.12

Sun, Y., Li, Q., Liu, L., Xu, C., Liu, Z., 2014. Hydrological simulation approaches for BMPs and LID practices in highly urbanized area and development of hydrological performance indicator system. Water Sci. Eng. 7, 143-154. https://doi.org/10.3882/j.issn.1674-2370.2014.02.003

Supharatid, S., Aribarg, T., Supratid, S., 2016. Assessing potential flood vulnerability to climate change by CMIP3 and CMIP5 models: case study of the 2011 Thailand great flood. J. Water Clim. Chang. 7, 52-67. https://doi.org/10.2166/wcc.2015.116

Suttles, K.M., Singh, N.K., Vose, J.M., Martin, K.L., Emanuel, R.E., Coulston, J.W., Saia, S.M., Crump, M.T., 2018. Assessment of hydrologic vulnerability to urbanization and climate change in a rapidly changing watershed in the Southeast U.S. Sci. Total Environ. 645, 806-816. https://doi.org/10.1016/j.scitotenv.2018.06.287

Tetzlaff, G., 2009. Extreme Rain and Wind Storms in Mid-Latitudes. Spring School on Fluid Mechanics and Geophysics of Environmental Hazards, Singapore.

Tetzlaff, G., Zimmer, J., 2013. Probable Maximum Precipitation (PMP) BT - Encyclopedia of Natural Hazards, in: Bobrowsky, P.T. (Ed.), . Springer Netherlands, Dordrecht, pp. 778-779. https://doi.org/10.1007/978-1-4020-4399-4_277

Tredway, J.C., Havlick, D.G., 2017. Assessing the Potential of Low-Impact Development 
Techniques on Runoff and Streamflow in the Templeton Gap Watershed, Colorado. Prof. Geogr. 69, 372-382. https://doi.org/10.1080/00330124.2016.1252272

Trinh, D.H., Chui, T.F.M., 2013. Assessing the hydrologic restoration of an urbanized area via an integrated distributed hydrological model. Hydrol. Earth Syst. Sci. 17, 47894801. https://doi.org/10.5194/hess-17-4789-2013

Tsai, Y.-J., Ho, H.-C., Lin, S.-W., Lee, H.-Y., 2019. Optimization of Low Impact Development Practices on Water Quantity and Quality using Multi-Objective Genetic Algorithm for Overdeveloped City., in: Geophysical Research Abstracts. 2019EGUGA..21.2849T (Vol. 21)

Vinet, F., 2018. Floods: Volume 2-Risk Management. ISTE Press-Elsevier, UK, 364p

Visitacion, B.J., Booth, D.B., Steinemann, A.C., 2009. Costs and benefits of storm-water management: Case study of the Puget Sound region. J. Urban Plan. Dev. 135, 150-158. https://doi.org/10.1061/(ASCE)0733-9488(2009)135:4(150)

Walsh, T.C., Pomeroy, C.A., Burian, S.J., 2014. Hydrologic modeling analysis of a passive, residential rainwater harvesting program in an urbanized, semi-arid watershed. J. Hydrol. 508, 240-253. https://doi.org/10.1016/j.jhydrol.2013.10.038

Wang, J., Tett, S.F.B., Yan, Z., 2017. Correcting urban bias in large-scale temperature records in China, 1980-2009. Geophys. Res. Lett. 44, 401-408. https://doi.org/10.1002/2016GL071524

Wang, K., Li, Z., Zhang, J., Wu, X., Jia, M., Wu, L., 2020. Built-up land expansion and its impacts on optimizing green infrastructure networks in a resource-dependent city. Sustain. Cities Soc. 55, 102026. https://doi.org/10.1016/j.scs.2020.102026

Wang, R., Purshouse, R.C., Fleming, P.J., 2013. Preference-Inspired Coevolutionary Algorithms for Many-Objective Optimization. IEEE Trans. Evol. Comput. 17, 474-494. https://doi.org/10.1109/TEVC.2012.2204264

Wang, T., Harvey, J.T., Jones, D., 2010. A Framework for Life-Cycle Cost Analyses and Environmental Life-Cycle Assessments for Permeable Pavements (Technical Memorandum). UC Davis: Institute of Transportation Studies, California, Sacramento. https://escholarship.org/uc/item/0f58m8x8

Wang, X., Huang, G., Liu, J., 2014. Projected increases in intensity and frequency of rainfall extremes through a regional climate modeling approach. J. Geophys. Res. Atmos. 119, 13,213-271,286. https://doi.org/10.1002/2014JD022564

Wang, X., Zhang, J., Shahid, S., Guan, E., Wu, Y., Gao, J., He, R., 2016. Adaptation to climate change impacts on water demand. Mitig. Adapt. Strateg. Glob. Chang. 21, 81- 
99. https://doi.org/10.1007/s11027-014-9571-6

Webb, L.B., Hennessy, K., 2015. Projections for selected Australian cities. CSIRO and Bureau of Meteorology, Australia. Accessed at https://www.climatechangeinaustralia.gov.au/media/ccia/2.1.6/cms_page_media/176/CC IA_Australian_cities_1.pdf.

Weiss, P.T., Gulliver, J.S., Erickson, A.J., 2005. The cost and effectiveness of stormwater management practices. Minnesota Department of Transportation, Research Services Section. University of Minnesota, MN, U.S.A

Wilbanks, T.J., Fernandez, S., 2014. Climate change and infrastructure, urban systems, and vulnerabilities: Technical report for the US Department of Energy in support of the national climate assessment. Island Press.88P.

WMO, 1985. Manual for Estimation of Probable Maximum Precipitation. World Meteorological Organization, Geneva, Switzerland.

World Bank, 2018. Data Bank: Urban population (\% of total population). https://data.worldbank.org/indicator/SP.URB.TOTL.IN.ZS

Wu, J., Wu, X., Zhang, J., 2019. Development Trend and Frontier of Stormwater Management (1980-2019): A Bibliometric Overview Based on CiteSpace. Water 11, 1908. https://doi.org/10.3390/w11091908

Wu, J., Yang, R., Song, J., 2018. Effectiveness of low impact development for urban inundation risk mitigation under different scenarios: a case study in Shenzhen, China. nat-hazards-earth-syst-sci.net 1-18. https://doi.org/10.5194/nhess-2017-402

Xie, X., Huo, J., Zou, H., 2019. Green process innovation, green product innovation, and corporate financial performance: A content analysis method. J. Bus. Res. 101, 697-706. https://doi.org/10.1016/j.jbusres.2019.01.010

Xu, T., Jia, H., Wang, Z., Mao, X., Xu, C., 2017. SWMM-based methodology for block-scale LID-BMPs planning based on site-scale multi-objective optimization: a case study in Tianjin. Front. Environ. Sci. Eng. 11, 1. https://doi.org/10.1007/s11783-017-0934-6

Yang, P., Ren, G., Hou, W., Liu, W., 2013. Spatial and diurnal characteristics of summer rainfall over Beijing Municipality based on a high-density AWS dataset. Int. J. Climatol. 33, 2769-2780. https://doi.org/10.1002/joc.3622

Yang, Y., Chui, T.F.M., 2018. Rapid assessment of hydrologic performance of low impact development practices under design storms. JAWRA J. Am. Water Resour. Assoc. 54, 613-630. https://doi.org/10.1111/1752-1688.12637

Yevjevich, V., 1994. Floods and society, in: Rossi G., Harmancioğlu N., Y.V. (eds) (Ed.), 
Coping with Floods. Springer, Dordrecht, pp. 3-9.

Yin, S., Li, W., Chen, D., Jeong, J.-H., Guo, W., 2011. Diurnal variations of summer precipitation in the Beijing area and the possible effect of topography and urbanization. Adv. Atmos. Sci. 28, 725. https://doi.org/10.1007/s00376-010-9240-y

Zahmatkesh, Z., Karamouz, M., Goharian, E., Burian, S.J., 2014. Analysis of the effects of climate change on urban storm water runoff using statistically downscaled precipitation data and a change factor approach. J. Hydrol. Eng. 20, 5014022. https://doi.org/10.1061/(ASCE)HE.1943-5584.0001064

Zeng, J., Huang, G., Mai, Y., Chen, W., 2020. Optimizing the cost-effectiveness of low impact development (LID) practices using an analytical probabilistic approach. Urban Water J. 17, 136-143. https://doi.org/10.1080/1573062X.2020.1748208

Zhan, W., Chui, T.F.M., 2016. Evaluating the life cycle net benefit of low impact development in a city. Urban For. Urban Green. 20, 295-304. https://doi.org/10.1016/j.ufug.2016.09.006

Zhang, K., Chui, T.F.M., 2018. A comprehensive review of spatial allocation of LID-BMPGI practices: Strategies and optimization tools. Sci. Total Environ. 621, 915-929. https://doi.org/10.1016/j.scitotenv.2017.11.281

Zhang, L., Sörensen, J., Yu, H., Li, J., Persson, K.M., 2016. Quantifying Low Impact Development Measures in Water Resources Management-A Case Study, in: International Low Impact Development Conference China 2016. Beijing, China.

Zhang, P., Chen, L., Hou, X., Wei, G., Zhang, X., Shen, Z., 2020. Detailed Quantification of the Reduction Effect of Roof Runoff by Low Impact Development Practices. Water 12, 795. https://doi.org/10.3390/w12030795

Zhang, X., Hu, M., 2014. Effectiveness of Rainwater Harvesting in Runoff Volume Reduction in a Planned Industrial Park, China. Water Resour. Manag. 28, 671-682. https://doi.org/10.1007/s11269-013-0507-9

Zhao, D., Miotto, A.B., Syal, M., Chen, J., 2019. Framework for Benchmarking green building movement: A case of Brazil. Sustain. Cities Soc. 48, 101545. https://doi.org/10.1016/j.scs.2019.101545

Zhao, G., Gao, H., Cuo, L., 2016. Effects of urbanization and climate change on peak flows over the San Antonio River Basin, Texas. J. Hydrometeorol. 17, 2371-2389. https://doi.org/10.1175/JHM-D-15-0216.1

Zhou, Q., Leng, G., Huang, M., 2018. Impacts of future climate change on urban flood volumes in Hohhot in northern China: benefits of climate change mitigation and 
adaptations. Hydrol. Earth Syst. Sci. 22, 305-316. https://doi.org/10.5194/hess-22-3052018

Zhu, Z., Chen, X., 2017. Evaluating the effects of low impact development practices on urban flooding under different rainfall intensities. Water 9, 548. https://doi.org/10.3390/w9070548

Zhu, Z., Chen, Z., Chen, X., Yu, G., 2019. An assessment of the hydrologic effectiveness of low impact development (LID) practices for managing runoff with different objectives. J. Environ. Manage. 231, 504-514. https://doi.org/10.1016/j.jenvman.2018.10.046

Zischg, J., Goncalves, M.L.R., Bacchin, T.K., Leonhardt, G., Viklander, M., van Timmeren, A., Rauch, W., Sitzenfrei, R., 2017. Info-Gap robustness pathway method for transitioning of urban drainage systems under deep uncertainties. Water Sci. Technol. 76, 1272-1281. https://doi.org/10.2166/wst.2017.320 